\title{
2004s-34 \\ Career Concerns of Top Executives, Managerial Ownership and CEO Succession
}

\author{
Martin Boyer, Hernan Ortiz Molina
}

Série Scientifique
Scientific Series

Montréal
Mai 2004

(C) 2004 Martin Boyer, Hernan Ortiz Molina. Tous droits réservés. All rights reserved. Reproduction partielle permise avec citation du document source, incluant la notice $(\mathrm{C}$.

Short sections may be quoted without explicit permission, if full credit, including $(\mathbb{C}$ notice, is given to the source.
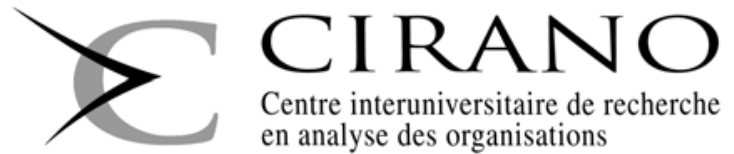

Centre interuniversitaire de recherche en analyse des organisations 


\section{CIRANO}

Le CIRANO est un organisme sans but lucratif constitué en vertu de la Loi des compagnies du Québec. Le financement de son infrastructure et de ses activités de recherche provient des cotisations de ses organisations-membres, d'une subvention d'infrastructure du ministère de la Recherche, de la Science et de la Technologie, de même que des subventions et mandats obtenus par ses équipes de recherche.

CIRANO is a private non-profit organization incorporated under the Québec Companies Act. Its infrastructure and research activities are funded through fees paid by member organizations, an infrastructure grant from the Ministère de la Recherche, de la Science et de la Technologie, and grants and research mandates obtained by its research teams.

\section{Les organisations-partenaires / The Partner Organizations}

PARTENAIRE MAJEUR

. Ministère du développement économique et régional et de la recherche [MDERR]

PARTENAIRES

. Alcan inc.

. Axa Canada

. Banque du Canada

. Banque Laurentienne du Canada

. Banque Nationale du Canada

. Banque Royale du Canada

. Bell Canada

. BMO Groupe Financier

. Bombardier

. Bourse de Montréal

. Caisse de dépôt et placement du Québec

. Développement des ressources humaines Canada [DRHC]

. Fédération des caisses Desjardins du Québec

. GazMétro

. Hydro-Québec

. Industrie Canada

. Ministère des Finances du Québec

. Pratt \& Whitney Canada Inc.

. Raymond Chabot Grant Thornton

. Ville de Montréal

. École Polytechnique de Montréal

. HEC Montréal

. Université Concordia

. Université de Montréal

. Université du Québec à Montréal

. Université Laval

. Université McGill

. Université de Sherbrooke

AssociE A :

. Institut de Finance Mathématique de Montréal $\left(\right.$ IFM $\left.^{2}\right)$

- Laboratoires universitaires Bell Canada

. Réseau de calcul et de modélisation mathématique $\left[\mathrm{RCM}^{2}\right]$

. Réseau de centres d'excellence MITACS (Les mathématiques des technologies de l'information et des systèmes complexes)

Les cahiers de la série scientifique $(\mathrm{CS})$ visent à rendre accessibles des résultats de recherche effectuée au CIRANO afin de susciter échanges et commentaires. Ces cahiers sont écrits dans le style des publications scientifiques. Les idées et les opinions émises sont sous l'unique responsabilité des auteurs et ne représentent pas nécessairement les positions du CIRANO ou de ses partenaires.

This paper presents research carried out at CIRANO and aims at encouraging discussion and comment. The observations and viewpoints expressed are the sole responsibility of the authors. They do not necessarily represent positions of CIRANO or its partners. 


\title{
Career Concerns of Top Executives, Managerial Ownership and CEO Succession
}

\author{
Martin Boyer ${ }^{*}$, Hernan Ortiz Molina ${ }^{\dagger}$
}

\begin{abstract}
Résumé / Abstract
Nous développons un modèle de choix de portefeuille des gestionnaires dans un environnement où leurs chances d'être promu PDG sont liées à leur actionnariat dans l'entreprise. Puisque les gestionnaires valorisent leur nomination potentielle au rang de PDG, nous prédisons que leur choix de portefeuille sera biaisé par rapport au choix qu'ils auraient fait en l'absence d'anticipations carriéristes. Notre modèle prédit que des changements dans les chances d'être promu expliquent les choix de portefeuille des gestionnaires. En particulier, nous montrons empiriquement qu'un plus grand actionnariat augmente la chance d'être promu au rang de PDG, réduit la chance qu'un gestionnaire externe à l'entreprise soit nommé. De plus, une réduction dans la possibilité d'être promu réduit l'actionnariat des gestionnaires ou induit leur départ. Nous testons les hypothèses découlant du modèle en utilisant les changements dans l'actionnariat des gestionnaire lors de la démission du PDG. Les hypothèses importantes du modèle sont confirmées.
\end{abstract}

Mots clés : rémunération des dirigeants, changement de PDG, tournoi corporatif, choix de portefeuille.

We model the portfolio decisions by managers with career concerns in a context where ownership of the firm's stock can affect the outcome of promotion contests. In addition to their utility from wealth, such managers derive utility from the monetary and non-monetary benefits (prestige) of running a corporation. Our theory predicts that top managers competing for the CEO position will distort their investment decisions away from the optimum portfolio choice in the absence of career concerns. Thus, our model suggests that changing career opportunities can explain portfolio decisions by managers and that insider ownership can help explain the outcomes of promotion contests. Our main testable predictions are that higher ownership by insiders increases their chances of being appointed CEO; that lower ownership by inside managers makes outside CEO appointments more likely; and that a lower probability of CEO turnover (and thus reduced promotion opportunities) leads inside managers to reduce their ownership in the firm and/or to leave the company. Using data on managerial ownership surrounding CEO turnover events, we find evidence supporting the predictions of our model. Overall, our main insight is that insider ownership, the outcome of promotion contests, the choice between inside and outside CEO replacements, and executive departure decisions are all related.

Keywords: managerial compensation, CEO succession, corporate tournament, portfolio allocation.

Codes JEL : G32, G34.

\footnotetext{
* CIRANO and HEC - Montréal, Université de Montréal, 3000 Côte-Ste-Catherine. Montréal, Quebec, H3T 2A7, email: martin.boyer@hec.ca.

${ }^{\dagger}$ Sauder School of Business, University of British Columbia.
} 


\section{Introduction}

Few positions in the economy are more prestigious and better compensated than that of chief executive officer (CEO) of a large corporation. CEO replacement decisions and the design of incentive mechanisms that induce CEOs and other top managers to maximize shareholder wealth are a main concern for the board of directors. Previous literature examines the role of promotion contests and the decision between inside and outside CEO replacements in inducing an optimal level of managerial effort. There is also a large literature on the determinants of top-management ownership. The evidence suggests that while the board of directors can use managerial ownership to align managerial and shareholder interest, it does not have full control over managerial ownership which is also driven by personal portfolio decisions by managers. However, both literatures assume that managerial portfolio decisions are independent of managers' interaction in promotion contests and of their career opportunities in the firm.

In this paper we build on the fact that managers have some control on their ownership in the firm and develop a model of managerial portfolio choice in the presence of career concerns. In addition to the utility they derive from their portfolio wealth allocation, such managers also derive utility from the monetary and non-monetary benefits (prestige) of running a corporation. Our main insight is that insider ownership, the outcome of promotion contests, the choice between inside and outside CEO replacements, and executive departure decisions are all related. Specifically, we model portfolio decisions by managers with career concerns in a context where ownership of the firm's stock can affect the outcome of promotion contests. A firm's board of directors makes appointment decisions based on each potential candidate's perceived managerial ability and the monetary cost to shareholders. The cost to shareholders consists in the board granting shares to the chosen candidate to increase her ownership from its current level to a pre-specified level that achieves an optimal incentive alignment. As a result, managers with higher ownership in the firm are less costly to appoint, so that managerial ownership affects the outcome of promotion contests to become CEO. Rational managers choose their ownership stakes in the firm taking this into account.

Our theory predicts that top managers competing for the CEO position will distort their investment decisions away from the optimum portfolio choice in the absence of career concerns. Specifically, career concerns induce managers to invest a larger fraction of their financial wealth in the firm's stock than the fraction suggested by basic diversification considerations. Thus, our model suggests that changing career opportunities can explain portfolio decisions by managers and that insider ownership can help explain the outcomes of promotion contests. Our four main testable predictions are that 1- higher ownership by insiders increases their chances of being appointed CEO; 2- lower ownership by inside managers makes outside CEO appointments more likely; 3- a lower probability of CEO turnover (and thus reduced promotion opportunities) leads inside managers to 
reduce their ownership in the firm or to leave the company; and 4- managers that owned a higher proportion of the firm's share should be the most disappointed managers when passed-up for a promotion.

Using data on managerial ownership surrounding CEO turnover events, we find statistically significant evidence supporting the predictions of our model. Our first set of tests concerns the role of managerial ownership on the outcome of promotion contests. Conditional on the decision to appoint an insider as the new CEO, we estimate the probability that any given insider will be appointed CEO. We find that insiders with higher ownership in the firm are more likely to be appointed, and that the probability of being appointed is substantially larger for managers with ownership in the top quintile. We then examine the board's decision to appoint CEO an insider or an outsider, conditional on the decision (necessity) to replace the incumbent CEO. We find that, even after controlling for other factors known to affect the inside/outside decision, firms are less likely to appoint an outsider when inside candidates have higher financial involvement with the corporation. Thus, our first set of results is consistent with our prediction that insider ownership affects CEO appointment decisions.

Our second set of tests examines changes in managerial ownership following the CEO replacement. Right after an appointment decision is made, the likelihood that a new opportunity to become CEO of the firm will arise in the short run drops dramatically. Thus, if the managers' portfolio decisions were biased towards investing in the firm's stock in the hopes of becoming CEO, then non-appointed executives will readjust their portfolios by reducing their financial involvement in the firm.

We find that, among all non-appointed insiders that stay in the firm after the CEO replacement, those with higher pre-event ownership (and higher pre-event ownership relative to other non-appointed insiders) are more likely to reduce their ownership in the firm than executives with lower pre-event ownership. The evidence suggests that non-appointed managers with higher ownership are those whose over-investment in the firm due to career concerns is more substantial, and thus are those more affected by the disappointing news about their career prospects. This result supports our theoretical model since we predict that high quality managers who are passed-up for the promotion to CEO would react more strongly than other managers. We do not know of any model where this reaction is predicted.

Finally, we examine non-appointed executive departure decisions following a firm's CEO replacement. We argue that one important decision for non-appointed top-managers facing less optimistic career prospects is whether to stay the company or leave in search of better prospects. We extend our model to incorporate the intuition that the reduced chances of competing for the CEO position may lead non-appointed executives with higher ownership to leave the company. The reason is that a manager's participation constraint may be more likely to bind following a reduction of the prob- 
ability of the CEO leaving the higher his financial stake in the corporation. In particular, we show that the higher is a manager's quality, the more he will disinvest in the firm following a new CEO appointment. As a result, the participation constraint of the more able manager is more likely to bind when his career concerns disappear. Because ownership in the firm is related to the manager's quality, the manager who is more likely to leave is the one who, compared to the other managers, had more money invested in the corporation. Thus, we expect executive departure decisions to be associated with higher pre-event ownership. Our results show that non-appointed insiders with higher ownership are more likely to leave the company than insiders with lower ownership. The evidence suggests that executives with higher ownership stakes are likely to be disappointed with the outcome of the contest and so that the reduction in their career opportunities helps explain their decision to leave the company.

Our paper is related to various research areas. The first is the literature on promotion contests. Starting with Lazear and Rosen (1981), Rosen (1986) and O'Reilly, Main and Chrystal (1988), the contest to become CEO (or the contest for any promotion) provides managers and workers at every level of the organization with the correct incentives to invest an optimal level of unobservable effort. ${ }^{1}$ Rather than designing an optimal tournament, we assume that managers always exert the optimal level of effort. The board in our model simply awards the prize to the executive that is expected to maximize the value of the firm net of the appointment cost. Because higher ownership by managers increases their chances of being appointed, competition in our model works through managerial investment in the firm rather than through effort levels. Our paper adds to the tournament literature by suggesting the portfolio choices by managers can affect the outcome of internal promotion contests.

There is also a large literature on CEO succession (see Parrino, 1997, Huson, Malatesta and Parrino, 2004, Tsoulouhas, Agrawal and Knoeber, 2003, and Agrawal, Knoeber and Tsoulouhas, 2003). This literature primarily focuses on the benefits of appointing an insider or an outsider at the helm of the corporation. Because the incentive to exert effort is provided to the firm's insiders through the contest to become CEO, it would be sub-optimal for the firm to appoint an outsider every time the incumbent CEO steps down because it would remove all the incentives for the insiders to try to win the contest. On the other hand, the appointment of an outsider brings new blood to the corporation in a way that may be more valuable to the firm, especially when the firm is performing poorly. Our work suggests that another important determinant of the inside/outside replacement decision is its cost to shareholders, and that everything else equal, a firm is less likely to appoint an outside CEO when current managers have high ownership in the firm.

We are aware of only one study that explores the fate of corporate insiders. Cannella and Shen

\footnotetext{
${ }^{1}$ See also Main et al. (1993), Chan (1996), Gibbons and Waldman (1999), Bognano (2001), Waldman (2003) and Gibbons and Waldman (2003).
} 
(2001) examine the behavior of CEO heirs apparent, which they identify by the title in the corporation (COO or president typically), and find that CEO heir apparent are more likely to become CEO. They do not examine, however, whether the ownership of the CEO heir apparent has any impact on the promotion or departure decision. They explain their decision to exclude ownership by stating that only a few of the CEO heirs apparent owned more than a minuscule proportion of their firm's common stock. ${ }^{2}$ Our study adds to theirs by showing that insider ownership is an important factor in exploring CEO appointment decisions.

Our work is directly related to the literature on the determinants of managerial ownership originated in Berle and Means (1932). These studies show that the variation in managerial incentives structures across firms is explained by differences in the contracting environment and the scope for moral hazard, and suggest that ownership of the firm's stock helps align managerial and shareholder interest (e.g., Himmelberg, Hubbard, and Palia, 1999). However, Ofek and Yermack (2000) show that managerial ownership stakes also reflect portfolio decisions by managers who can undo any incentive effect of new stock and stock option grants by selling previously owned shares. In addition, they show that when managers exercise options to acquire stock, nearly all of the shares are sold, thus reducing their financial involvement with the firm. Core and Guay (1999) estimate optimal incentive levels as a function of its economic determinants, and show that the board uses stock and stock option grants to correct deviations of managerial ownership from its optimal incentive level. Thus, the evidence suggests that observed ownership stakes reflect the tension between a board's goals of incentive alignment and executives desires to diversify their portfolios for risk reduction. While these studies recognize that managerial ownership reflects, at least in part, optimal portfolio considerations driven by managers' concern about firm-specific risk, there is no theory connecting managerial portfolio decisions and career opportunities within a firm. In our model, managerial portfolio decisions reflect the trade-off between diversification incentives and the positive effect of ownership on the outcome of promotion contests. Thus, while diversification considerations only explain why managers would like to reduce their ownership, we suggest that career opportunities are a reason for managers to invest more of their wealth in the firm.

Our paper fits in the intersection of these strands of the literature. We provide a model where top-management portfolio decisions are driven by career concerns because managers can increase their chances of promotion by increasing their ownership stake in the firm. In our model the firm can appoint CEO any of the insider executives or can choose to appoint an outsider with no ownership

\footnotetext{
${ }^{2}$ We see four possible explanations for this. First, Canella and Shen's sample, from 1986 to 1996, pre-dates the explosion in the use of stock compensation for managers. Second, they do not appear to have considered stock options on top of restricted stocks. Third, following Vancil (1987), their measure of heir apparent is biaised toward more public figure in the corporation since he is identified by his title in the corporation (COO or president typically). This may not be the person that has the highest ownership in the corporation. Fourth, the SEC rules on insider ownership and compensation disclosure were made mode stringent in 1992 so that all pertinent information was perhaps not available for Canella and Shen's sample years.
} 
in the firm. Because any appointed executive receives additional shares so as to induce her to reach a pre-specified target ownership level, the cost of appointing any given executive decreases in her ex-ante ownership. Thus, ex-ante ownership by managers affects the outcome of promotion contests. This connection between managerial portfolio decisions, career concerns, and the outcome of promotion contests allows us to derive unique predictions that are supported by the data.

Our paper is also related to a recent study by Hayes, Oyer and Schaffer (2002). They find a positive relation between CEO turnover and the turnover of non-CEO managers, especially when the new CEO is appointed from outside the firm. The authors interpret their evidence as consistent with the hypothesis that firms are run by management teams. Thus, they argue that when a CEO is replaced the entire management team is likely to be replaced or follow the CEO to a new firm. Our results suggest another possible explanation. Top managers who lose the contest to become CEO reduce their financial involvement in the firm or leave the firm altogether because their probability of being appointed CEO in the future, and the expected size of the prize, has been reduced. In other words, the intuition in our model suggests that top managers are more likely to leave the company after an outside CEO replacement because this conveys negative information about their career prospects if they stay with the firm. While the positive association between CEO and non-CEO managerial turnover can be explained by either management teams or our career concerns story, only our theory can explain the reduction in managerial ownership by non-appointed managers following CEO turnover.

The remainder of the paper is organized as follows. Section 2 presents our model and its basic implications. Section 3 presents the data and variable description. We present the main empirical results of the paper in Section 4. We discuss out results in Section 5 and conclude with Section 6.

\section{Model}

The economy is composed of $M+N$ individuals that may become the firm's CEO when the incumbent CEO leaves. ${ }^{3}$ Each individual is endowed with some level of managerial quality $Q_{i}$. A company employs a number $M$ of individuals whom we refer to as the managers. Each of these managers is endowed with some managerial quality level $Q_{m}$. The $N$ potential CEOs that are outside the corporation, whom we refer to as the outsiders, are endowed with managerial quality $Q_{n}$. A more qualified CEO is better able to increase the value of the corporation. Contingent on the CEO having managerial quality $Q_{i}$ the firm's value is $V\left(\alpha^{*}\right)+Q_{i}$, where $\alpha^{*}$ is the level of incentive alignment awarded to the CEO. Core and Guay (1999) show that corporations aim for some optimal level of CEO ownership to align their incentives with those of the shareholders.

The timing of the game is the following. First, the board of directors, on behalf of the firm's

\footnotetext{
${ }^{3}$ This is not the total population of the economy. Potential CEOs are only a small subset of all the managers in the economy, which is a very small subset of the total population.
} 
shareholders, chooses a level of incentive alignment $\left(\alpha^{*}\right)$ that it wants to provide to the CEO. ${ }^{4}$ This level of alignment is chosen in order to maximize effort by any individual that occupies the CEO position. This $\alpha^{*}$ is known to every player in the game. Each manager is endowed with some initial wealth $W_{m}$ that he can use to purchase the company's stock or to purchase the market portfolio. ${ }^{5}$ Managerial quality is known to every manager but unknown to the board of directors and to the shareholders.

Knowing the corporation's CEO ownership target level, $\alpha^{*}$, and knowing the initial wealth $W_{m}$ of every manager, each manager decides what proportion $\omega_{m}$ of his wealth to invest in the market portfolio and what proportion $1-\omega_{m}$ to invest in the firm's stock. Ofek and Yermack (2001) show that managers have control over their ownership in the firm. Specifically. they show that managers can undo the effect of more stock options and restricted stock grants by selling previously owned shares. A similar argument is made by Kole (1997) who states that although managers receive restricted stocks and stock options that vest over time, the short vesting schedule associated with these grants is more consistent with compensatory purposes than incentive alignment. This may be even more prominent since the million dollar rule (see Rose and Wolfram, 2001). As a result, we assume in our model that managers are able to allocate as much wealth as they want between the market and the firm's stock.

Nature then chooses whether the incumbent CEO leaves the firm. With some exogenous probability $\rho$, the CEO leaves.

Given the CEO's departure, the firm's shareholders (or the firm' board of directors) receive $N+$ $M$ signals related to the managerial quality of each potential CEO. Let $\Lambda=\left(\lambda_{m_{1}}, \ldots, \lambda_{M}, \lambda_{n_{1}}, \ldots, \lambda_{N}\right)$ represent the vector of the $N+M$ signals that the board receives. The vector of signals is divided into $M$ signals $\lambda_{m}$ related to managerial quality of each inside manager and $N$ signals $\lambda_{n}$ related to the managerial quality of the outside candidates. This vector of signals is only observed by the board and is independent of the players' action. After receiving the signals and knowing the ownership level of the corporation's non-CEO managers, the board chooses as CEO the manager who provides the greatest benefit to the corporation's shareholders at the lowest possible cost. Finally, managers can alter the composition of their portfolios after observing the appointment decision. Figure 1 presents the timing of the game schematics.

\subsection{Incentive alignment}

In the event that a CEO steps down, voluntarily or not, from his position in the corporation, the corporation's board of directors must appoint a new CEO. The directors' choice is to appoint

\footnotetext{
${ }^{4}$ The corporate tournament literature in general and Lazear and Rosen (1981) in particular state that aligning the CEO's incentive is sufficient for every other person's incentive to be aligned in the corporation.

${ }^{5}$ For example, a manager's wealth have may been accumulated over the years from his salary in the company so that $W_{t m}=\sum_{\tau=\bar{t}_{m}}^{t} w_{\tau m}$, where $\bar{t}_{m}$ is the year where the manager joined the firm.
} 
Figure 1: Sequence of event in the game.

\begin{tabular}{|c|c|c|c|c|c|}
\hline \multirow{2}{*}{$\begin{array}{l}\text { After observing } \\
\alpha^{*}, \rho, W_{m} \forall m \\
\text { and knowing } Q_{m} \\
\forall m, \text { managers } \\
\text { choose } \omega_{m} .\end{array}$} & \multirow{2}{*}{$\begin{array}{c}\text { Nature } \\
\text { decides } \\
\text { whether } \\
\text { CEO stays } \\
\text { or leaves. }\end{array}$} & $\begin{array}{l}\text { CEO } \\
\text { stays }\end{array}$ & \multicolumn{2}{|c|}{ Nothing happens } & \multirow{2}{*}{$\begin{array}{c}\text { Payoffs } \\
\text { are paid } \\
\text { and the } \\
\text { game } \\
\text { ends }\end{array}$} \\
\hline & & $\begin{array}{l}\text { CEO } \\
\text { leaves } \\
\rho\end{array}$ & $\begin{array}{c}\text { Signal } \lambda_{i} \text { of each } \\
\text { individual's quality } \\
Q_{i} \text { observed by } \\
\text { the board. }\end{array}$ & $\begin{array}{c}\text { Board } \\
\text { appoints } \\
\text { new CEO }\end{array}$ & \\
\hline
\end{tabular}

someone from within the firm (an inside manager, which we will index by $m$ ) or someone that comes from the outside (an outsider, which we will index by $n$ ). In both cases, the board wants to provide the newly appointed CEO with some level of incentive $\alpha^{*}$ so that the new CEO's preferences are aligned with those of the shareholders. To maximize the value of the corporation, the board would like the CEO to hold some proportion of the firm's shares. A manager's ownership level is given by $\alpha_{m}$ that represents the proportion of the firm's shares that each manager $m$ holds. $\alpha_{m}$ is common knowledge. For the firm outsiders, we assume that they do not own any shares in the corporation so that $\alpha_{n}=0 \forall n \in N$.

Each potential CEO $i \in N+M$ is endowed with some quality $Q_{i}$ that has an impact on the value of the firm only if appointed CEO. The impact consists in a discrete jump in the value of the firm corresponding to the manager's quality. Let the value of the firm be separable in managerial ownership (or incentive) and in managerial quality such that $V(\alpha, Q)=v(\alpha)+Q$. The choice of $\alpha$ will then be the solution to $\alpha^{*}=\arg \max [v(\alpha)+Q]=\arg \max v(\alpha)$. We then have that the value of the corporation is given by $V\left(\alpha^{*}, Q\right)$ for some level of incentive equal to $\alpha^{*}$. Without loss of generality, we shall normalize the incumbent CEO's quality to $Q_{0}=0$. Let then $V_{0}=\left.V^{*}\left(\alpha^{*}, Q\right)\right|_{Q=0}$ represent the value of the company under the incumbent CEO. When a replacement that has quality $Q_{i}$ is appointed CEO, the value of the corporation becomes $V_{i}=V_{0}+Q_{i}$. The new CEO may have a quality that is smaller (i.e., $Q_{i}<0$ ) or larger (i.e., $Q_{i}>0$ ) than the departing CEO. A important assumption we make is that the optimum level of incentive provided to the CEO, $\alpha^{*}$, is independent of the CEO's quality ${ }^{6}$. As a result, the shareholders' wealth will be given by $\left(1-\alpha^{*}\right)\left(V_{0}+Q_{i}\right)$ when an individual who is endowed with quality $Q_{i}$ is appointed as the new CEO.

If no manager owns any shares in the firm, the board would like to appoint as CEO the individual

\footnotetext{
${ }^{6}$ One possible rationale for this assumption is that every potential CEO holds the same preference for the activities that require incentive alignment and that every potential CEO faces the same cost of effort. As a result, we can view each individual's quality as a lump-sum benefit to the corporation that has no impact on the optimal incentive contract and on the level of effort invested.
} 
who provides shareholders will the greatest benefit after the incentive alignment cost has been spent. In other words, the board would like to appoint CEO the individual for whom $\left(1-\alpha^{*}\right)\left(V_{0}+Q_{i}\right)$ is the greatest. If every firm manager $m \in M$ is endowed with some ownership in the firm, $\alpha_{m}$, the true cost to the shareholders of appointing an insider is $\left(\alpha^{*}-\alpha_{m}\right)\left(V_{0}+Q_{i}\right)$. On the other hand, the cost of appointing as CEO a firm outsider is $\alpha^{*}\left(V_{0}+Q_{i}\right)$ because outsiders do not own any of the firm's shares, so that $\alpha_{n}=0$. As a result the board would like to appoint CEO the individual for whom $\left(1-\alpha^{*}+\alpha_{i}\right)\left(V_{0}+Q_{i}\right)$ is the greatest.

\subsection{The shareholders' choice}

When the incumbent CEO steps down from his position as head of the corporation, shareholders would like to appoint in her place the person who will maximize their wealth. Shareholders know that each potential CEO is endowed with some managerial quality $Q_{i}$ that follows some common knowledge distribution. This means that the value of the firm that appoints as CEO an individual that is endowed with managerial quality $Q_{i}$ is $V_{0}+Q_{i}$. Although the quality is independent of the CEO's level of incentive, the value of the firm, net of the quality of the CEO, is assumed to be maximized only if the CEO is given some level of incentive $\alpha^{*}$. By assumption, the level of incentive that maximizes the value of the firm is independent of the manager's quality.

Because managerial quality unknown to the board and to the shareholders, the board's decision to appoint any person CEO depends on the its belief regarding every manager's quality and ownership in the firm. The board does not observe any individual's quality, but it does observe some noisy signal $\lambda_{i}$ that is correlated with it. This means that after observing the signal and knowing each manager's ownership in the firm,${ }^{7}$ the board's posterior belief of each manager's quality is $q_{m}\left(\lambda_{m}, \alpha_{m}\right)=E\left[Q_{m} \mid \lambda_{m}, \alpha_{m}\right]$. Similarly, the board's posterior belief regarding any outsider's quality is $q_{n}\left(\lambda_{n}\right)=E\left[Q_{n} \mid \lambda_{n}\right]$.

In order to give the $\mathrm{CEO}$ a level of incentive equal to $\alpha^{*}$, shareholders must sacrifice some wealth by sharing the value of the firm with the CEO. Shareholders will therefore appoint as CEO the individual who maximizes their wealth net of the incentive alignment cost. Given that shareholders perceive each inside manager as being of quality $q_{m}\left(\lambda_{m}, \alpha_{m}\right)$ and each outsider as being of quality $q_{n}\left(\lambda_{n}\right)$, they expect the ex post value of the firm to be $V_{0}+q_{i}$, for $i \in N+M$.

The benefit of appointing anyone as CEO must be compared to the cost. The expected cost of appointing an outsider, whose has expected quality $q_{n}$, is $\alpha^{*}\left(V_{0}+q_{n}\right)$ because, by assumption, outsiders do not own any of the corporation's shares. On the other hand, the expected cost of

\footnotetext{
${ }^{7}$ Managers may use their ownership in the firm to signal their quality. As a result, the board of directors will adapt their beliefs regarding any manager's quality according to the two signals that it receives. Say that $f\left(Q_{m}\right)$ is the ex-ante distribution of every manager's quality. By construction, let $E\left(Q_{m}\right)=0$. Conditional on Nature's signal, $\lambda_{m}$, and on the manager's signal, $\alpha_{m}$, regarding $Q_{m}$, the board updates its beliefs regarding the manager's quality so that the conditional distribution becomes $f\left(Q_{m} \mid \lambda_{m}, \alpha_{m}\right)$. The expected quality of the manager then becomes $q_{m}\left(\lambda_{m}, \alpha_{m}\right)=E\left(Q_{m} \mid \lambda_{m}, \alpha_{m}\right)$.
} 
appointing as CEO an inside manager who has expected quality $q_{m}$ is $\left(\alpha^{*}-\alpha_{m}\right)\left(V_{0}+q_{m}\right)$ since the insider already owns some proportion $\alpha_{m}$ of the company. As a result, the person who will be appointed $\mathrm{CEO}$ will be the one that provides shareholders with the greatest expected net benefit so that an individual is appointed CEO if

$$
\left(1-\alpha^{*}+\alpha_{i}\right)\left(V_{0}+q_{i}\left(\lambda_{i}, \alpha_{i}\right)\right) \geq\left(1-\alpha^{*}+\alpha_{j}\right)\left(V_{0}+q_{j}\left(\lambda_{j}, \alpha_{j}\right)\right) \quad \forall j \neq i
$$

Condition (1) implicitly defines the probability that any given manager is appointed CEO, $\gamma_{m}\left(q_{m}, q_{-m}, \alpha_{m}, \alpha_{-m}\right)$, conditional on a CEO replacement taking place. Thus, we establish the following proposition:

Proposition $1 \gamma_{m}\left(q_{m}, q_{-m}, \alpha_{m}, \alpha_{-m}\right)$ is increasing in $q_{m}$ and $\alpha_{m}$ and decreasing in $q_{-m}$ and $\alpha_{-m}$.

The probability that some individual will be appointed CEO, conditional on the incumbent CEO stepping down, depends positively on his quality and on his ownership in the firm. The reason is that shareholders want to appoint the person with the highest expected quality given the observed signal, $q_{i}\left(\lambda_{i}, \alpha_{i}\right)$, and they want to appoint the person that has the lowest appointment cost, $\alpha^{*}-\alpha_{i}$. The probability will also depend negatively on the signal that the shareholders receive from the other individuals, $q_{-i}\left(\lambda_{-i}, \alpha_{-i}\right)$, and on the other managers' ownership in the firm, $\alpha_{-i}$.

Because outsiders are assumed to have no ownership in the firm, the relative cost of hiring an outsider rather than an insider is lower when insider ownership is low. This allow us to state the main implication of (1).

Implication: Everything else constant, the board is more likely to appoint an outsider when insider ownership is low.

\subsection{The manager's strategy}

In addition to their wealth associated with their portfolio allocation return, managers are able to increase their wealth if they are happen to run a corporation. There are two components to this extra wealth associated with running a corporation. First, the manager may receive a higher monetary income $G$. Second, he may be given shares in the corporation so that his level of incentive goes from $\alpha_{m}$ to $\alpha^{*}$.

At the beginning of the game, each manager is endowed with some wealth $W_{m}$ that can be invested in the firm's stock or in the market portfolio. Each manager decides what proportion $1-\omega_{m}$ of their wealth to invest in the firm's shares and what proportion $\omega_{m}$ to invest in the market portfolio. Short selling of either the market portfolio or the firm's stock is not allowed so that $\omega_{m} \in[0,1]$. Moreover, managers cannot borrow. 
The return of a market portfolio follows a Normal distribution with mean $\mu_{P}$ and standard deviation $\sigma_{P}: R_{P} \mathcal{N}\left(\mu_{P}, \sigma_{P}\right)$. Similarly, the return on the firm's stock also follows a Normal distribution with mean $\mu_{F}$ and standard deviation $\sigma_{F}:: R_{F^{\sim}} \mathcal{N}\left(\mu_{F}, \sigma_{F}\right)$. For simplicity, we will assume that the market portfolio's mean return is the same as the firm's mean stock return, but that the risk of the firm's stock return is greater than the market's. In other words, the return on the market portfolio first degree stochastically dominates the return on the firm's stock (i.e., $\mu_{P}=\mu_{F}$ and $\left.\sigma_{P}<\sigma_{F}\right)$.

Absent career concerns, each manager chooses a proportion $\omega_{m}$ of his total wealth to invest in the market portfolio and a proportion $1-\omega_{m}$ to invest in the firm's stock to maximize his expected utility over final wealth: $\iint U\left[W_{m}\left(\omega_{m} R_{P}+\left(1-\omega_{m}\right) R_{F}\right)\right] d F\left(R_{P}\right) d H\left(R_{F}\right)$. Suppose now that managers could be given some amount of money $\widetilde{Y}$ that is independent of the firm's stock return and of the market portfolio return. Because $\widetilde{Y}$ is not affected by the distribution of either return, it will have an impact only on the manager's expected final portfolio wealth, but not on the variance of that wealth.

Since all returns are distributed normally, we can separate the expected utility function between in its two arguments: return and risk. Let

$$
\widetilde{U}\left[\omega_{m} \mu_{P}+\left(1-\omega_{m}\right) \mu_{F}+\tilde{Y}, \omega_{m}^{2} \sigma_{P}^{2}+\left(1-\omega_{m}\right) \sigma_{F}^{2}+2\left(1-\omega_{m}\right) \omega_{m} \sigma_{F P}\right]
$$

represent such a expected utility transform. Because $\mu_{P}=\mu_{F}$, the expected utility transform may be rewritten as

$$
\widetilde{U}\left[\mu_{P}+\widetilde{Y}, \sigma^{2}\left(\omega_{m}\right)\right]
$$

where $\sigma^{2}\left(\omega_{m}\right)=\omega_{m}^{2} \sigma_{P}^{2}+\left(1-\omega_{m}\right)^{2} \sigma_{F}^{2}+2\left(1-\omega_{m}\right) \omega_{m} \sigma_{F P}$. The choice variable of this function is $\omega_{m}$.

An individual who is only concerned about the return on his investment portfolio (in other words an individual where $\tilde{Y}=0$ always) would invest a proportion $1-\omega_{m}=\frac{\sigma_{P}^{2}-\sigma_{F P}}{\sigma_{F}^{2}+\sigma_{P}^{2}-2 \sigma_{F P}}$ in his firm and a proportion $\omega_{m}=\frac{\sigma_{F}^{2}-\sigma_{F P}}{\sigma_{F}^{2}+\sigma_{P}^{2}-2 \sigma_{F P}}$ in the market portfolio. Let us see what happens when the manager has career concerns so that he perceives that his chance of becoming CEO is dependent on his personal financial involvement with the corporation.

There are two benefits of becoming CEO in our model. The first is independent of the manager's portfolio decision and the second depends on the manager's portfolio decision. Let the independent prize be given by $G$. This fixed benefit includes the monetary equivalent of the prestige associated with being named the CEO of the corporation, ${ }^{8}$ the increase in his salary and the monetary benefits that one may receive by being appointed on the board of directors of other corporations.

For the benefit that is dependent on the manager's portfolio decision, he will be given enough shares to own a proportion $\alpha^{*}$ of the corporation if appointed CEO. Given that each manager

\footnotetext{
${ }^{8}$ Note that our results do not change if we allow the manager's utility to be separable in wealth and in prestige.
} 
already owns a proportion $\alpha_{m}$ and that each manager is endowed with some managerial quality $Q_{m}$, the net benefit to a manager of being appointed CEO is $\left(\alpha^{*}-\alpha_{m}\right)\left(V_{0}+Q_{m}\right)$. On top of this, every manager also observes a variation in the value of the shares he already owns. This means that if manager $m$ is appointed CEO, the benefit he receives (or the loss he bears) is equal to $\alpha_{m} Q_{m}$. The total benefit to the manager of being appointed $\mathrm{CEO}$ is therefore $Z=$ $G+\left(\alpha^{*}-\alpha_{m}\right)\left(V_{0}+Q_{m}\right)+\alpha_{m} Q_{m}$. If manager $m$ is not appointed CEO, his benefit (or loss) is $\alpha_{m} Q_{-m}$ for all other possible managers.

Let $\mathbf{1}_{C E O}$ be an indicator function that equals 1 if the CEO quits the corporation and 0 otherwise (recall that the managers cannot do anything to alter the CEO's probability of leaving the firm). Also, let $\mathbf{1}_{m}\left(q_{m}, q_{-m}, \alpha_{m}, \alpha_{-m}\right)$ represent an indicator function that equals 1 if manager $m$ is appointed CEO and zero otherwise. This indicator function depends on the board's posterior belief regarding the managers' quality, $q_{m}\left(\lambda_{m}, \alpha_{m}\right)$ and $q_{-m}\left(\lambda_{-m}, \alpha_{-m}\right)$, on manager $m$ 's ownership, $\alpha_{m}$, and the stock ownership of the other players, $\alpha_{-m}$.

Because managers behave strategically, they know that their portfolio choice will have an impact on the behavior of the other managers. They also know that shareholders will use their financial involvement in the firm as a signal of their quality. In other words, $\frac{\partial \alpha_{-m}}{\partial \alpha_{m}} \geq 0$ and $\frac{\partial q_{m}}{\partial \alpha_{m}} \geq 0$. This means that the marginal probability that manager $m$ is appointed CEO, as a function of his ownership in the firm is

$$
\frac{d \pi_{m}}{d \alpha_{m}}=\frac{\partial \pi_{m}}{\partial q_{m}} \frac{\partial q_{m}}{\partial \alpha_{m}}+\sum_{x \neq m}^{M+N} \frac{\partial \pi_{m}}{\partial q_{x}} \frac{\partial q_{x}}{\partial \alpha_{x}} \frac{\partial \alpha_{x}}{\partial \alpha_{m}}+\frac{\partial \pi_{m}}{\partial \alpha_{m}}+\sum_{x \neq m}^{M+N} \frac{\partial \pi_{m}}{\partial \alpha_{x}} \frac{\partial \alpha_{x}}{\partial \alpha_{m}}
$$

Assuming that shareholders treat every CEO candidate symmetrically, $\frac{\partial \pi_{m}}{\partial \alpha_{m}}=\frac{\partial \pi_{x}}{\partial \alpha_{x}}$ and $\frac{\partial \pi_{m}}{\partial q_{m}}=$ $\frac{\partial \pi_{x}}{\partial q_{x}}$ must be true for all $x$. Because $\pi_{m}+\sum_{x \neq m}^{M+N} \pi_{x}=1$, we have that $\frac{\partial \pi_{m}}{\partial q_{m}}+\sum_{x \neq m}^{M+N} \frac{\partial \pi_{x}}{\partial q_{m}}=0$, $\frac{\partial \pi_{m}}{\partial q_{j}}+\sum_{x \neq m}^{M+N} \frac{\partial \pi_{x}}{\partial q_{j}}=0, \frac{\partial \pi_{m}}{\partial \alpha_{m}}+\sum_{x \neq m}^{M+N} \frac{\partial \pi_{x}}{\partial \alpha_{m}}=0$ and $\frac{\partial \pi_{m}}{\partial \alpha_{j}}+\sum_{x \neq m}^{M+N} \frac{\partial \pi_{x}}{\partial \alpha_{j}}=0$. Substituting where applicable and factoring the terms, we find

$$
\frac{d \pi_{m}}{d \alpha_{m}}=\left(\frac{\partial \pi_{m}}{\partial q_{m}} \frac{\partial q_{m}}{\partial \alpha_{m}}+\frac{\partial \pi_{m}}{\partial \alpha_{m}}\right)\left[1-(N+M-1) \sum_{x \neq m}^{M+N} \frac{\partial \alpha_{x}}{\partial \alpha_{m}}\right]
$$

Given that a Nash equilibrium is possible only if $(N+M-1) \sum_{x \neq m}^{N+M} \frac{\partial \alpha_{x}}{\partial \alpha_{m}}<1$ (see Tirole, 1988), ${ }^{9}$ we are able to say that $\frac{d \pi_{m}}{d \alpha_{m}}>0$. In other words, the probability that one manager is appointed CEO increases in his ownership in the firm.

We can then write the manager's expected utility maximization problem as

$$
\max _{\omega_{m}} E U=E_{\Lambda}\left\{\begin{array}{c}
\left(1-\mathbf{1}_{C E O}\right) \widetilde{U}\left[\mu_{P}, \sigma^{2}\left(\omega_{m}\right)\right] \\
+\mathbf{1}_{C E O} \mathbf{1}_{m}\left(q_{m}, q_{-m}, \alpha_{m}, \alpha_{-m}\right) \widetilde{U}\left[\mu_{P}+Z, \sigma^{2}\left(\omega_{m}\right)\right] \\
+\mathbf{1}_{C E O} \sum_{x \neq m}^{M+N} \mathbf{1}_{x}\left(q_{x}, q_{-x}, \alpha_{x}, \alpha_{-x}\right) \widetilde{U}\left[\mu_{P}+\alpha_{m} Q_{x}, \sigma^{2}\left(\omega_{m}\right)\right]
\end{array}\right\}
$$

\footnotetext{
${ }^{9}$ In particular, consider what happens when $N+M=2$ so that there are only two managers that are competing for the prize. We then have $\frac{d \pi_{m}}{d \alpha_{m}}=\left(\frac{\partial \pi_{m}}{\partial q_{m}} \frac{\partial q_{m}}{\partial \alpha_{m}}+\frac{\partial \pi_{m}}{\partial \alpha_{m}}\right)\left[1-\frac{\partial \alpha_{x}}{\partial \alpha_{m}}\right]$, which clearly holds from the two-person game equilibrium condition: $\left|\frac{\partial \alpha_{x}}{\partial \alpha_{m}}\right|<1$.
} 
The first term is the utility that the manager receives if the incumbent CEO does not step down from his post. The second term is the utility that manager $m$ receives is he is appointed CEO when the incumbent CEO steps down. The $M+N-1$ last terms are the utilities that manager $m$ receives if any other of the $N+M-1$ contenders is not appointed CEO when the incumbent CEO steps down.

Let $\rho=E_{\Lambda}\left[\mathbf{1}_{C E O}\right]$ and let $\pi_{j}=E_{\Lambda}\left[\mathbf{1}_{m}\left(q_{m}, q_{-m}, \alpha_{m}, \alpha_{-m}\right)\right]$. By distributing the expectation operator through problem $(2)^{10}$ we can rewrite is as

$$
\begin{aligned}
\max _{\omega_{m}} E U= & (1-\rho) \widetilde{U}\left[\mu_{P}, \sigma^{2}\left(\omega_{m}\right)\right] \\
& +\rho \pi_{m}\left(q_{m}, q_{-m}, \alpha_{m}, \alpha_{-m}\right) \widetilde{U}\left[\mu_{P}+Z, \sigma^{2}\left(\omega_{m}\right)\right] \\
& +\rho \sum_{x \neq m} \pi_{x}\left(q_{x}, q_{-x}, \alpha_{x}, \alpha_{-x}\right) \widetilde{U}\left[\mu_{P}+\alpha_{m} Q_{x}, \sigma^{2}\left(\omega_{m}\right)\right]
\end{aligned}
$$

This allows us to state the main result of our our model.

Theorem 1 The (implicit) solution to the manager's maximization problem ${ }^{11}$ is

$$
\omega_{m}=\frac{\sigma_{F}^{2}-\sigma_{F P}}{\sigma_{P}^{2}+\sigma_{F}^{2}-2 \sigma_{F P}}+\frac{\rho W_{m}}{V_{0}} \frac{A / 2 B}{\sigma_{P}^{2}+\sigma_{F}^{2}-2 \sigma_{F P}}
$$

where

$$
\begin{aligned}
A= & \frac{d \pi_{m}}{d \alpha_{m}} \widetilde{U}\left[\mu_{P}+Z, \sigma^{2}\left(\omega_{m}\right)\right]-\pi_{m} \widetilde{U}_{1}\left[\mu_{P}+Z, \sigma^{2}\left(\omega_{m}\right)\right] V_{0} \\
& +\sum_{x \neq m} \frac{d \pi_{x}}{d \alpha_{m}} \widetilde{U}\left[\mu_{P}+\alpha_{m} Q_{x}, \sigma^{2}\left(\omega_{m}\right)\right]+\sum_{x \neq m} \pi_{x} \widetilde{U}_{1}\left[\mu_{P}+\alpha_{m} Q_{x}, \sigma^{2}\left(\omega_{m}\right)\right] Q_{x}
\end{aligned}
$$

and

$$
\begin{aligned}
B= & (1-\rho) \widetilde{U}_{2}\left[\mu_{P}, \sigma^{2}\left(\omega_{m}\right)\right]+\rho \pi_{m} \widetilde{U}_{2}\left[\mu_{P}+Z, \sigma^{2}\left(\omega_{m}\right)\right] \\
& +\rho \sum_{x \neq m} \pi_{x} \widetilde{U}_{2}\left[\mu_{P}+\alpha_{m} Q_{x}, \sigma^{2}\left(\omega_{m}\right)\right]
\end{aligned}
$$

Proof: See appendix.

The first term represents the proportion of each manager's wealth that he invests in the market portfolio if he has no career concerns about becoming the firm's CEO. In other words, if $\rho=0$, then each manager's optimal wealth allocation is such that he invests a proportion $1-\omega_{m}=\frac{\sigma_{P}^{2}-\sigma_{F P}}{\sigma_{P}^{2}+\sigma_{F}^{2}-2 \sigma_{F P}}$ in the firm. When managers have career concerns, our contention is that they will increase the proportion of their wealth that they invest in the firm's stock so that $\omega_{m}$ should decrease. In other words, the second term should be negative.

\footnotetext{
${ }^{10}$ Recall that every manager knows the quality of all the possible successors so that, from the point of view of the manager, $\widetilde{U}[\bullet]$ is a constant.

${ }^{11}$ Note that the second order condition holds.
} 
For this to happen, we need $A / B$ to be negative since all other terms are positive. Clearly $B$ is negative since managers dislike variance so that $\widetilde{U}_{2}<0$ always. All that is left to show is the sign of $A$. A necessary condition for $A>0$ is that $\frac{d \pi_{m}}{d \alpha_{m}}>0$. Another condition is for the size of the firm, $V_{0}$, to be large enough. To see why, rewrite $A$ as

$$
\begin{aligned}
A= & \frac{d \pi_{m}}{d \alpha_{m}} \widetilde{U}\left[\mu_{P}+Z, \sigma^{2}\left(\omega_{m}\right)\right]+\sum_{x \neq m} \frac{d \pi_{x}}{d \alpha_{m}} \widetilde{U}\left[\mu_{P}+\alpha_{m} Q_{x}, \sigma^{2}\left(\omega_{m}\right)\right] \\
& -\pi_{m} \widetilde{U}_{1}\left[\mu_{P}+Z, \sigma^{2}\left(\omega_{m}\right)\right] V_{0}+\sum_{x \neq m} \pi_{x} \widetilde{U}_{1}\left[\mu_{P}+\alpha_{m} Q_{x}, \sigma^{2}\left(\omega_{m}\right)\right] Q_{x}
\end{aligned}
$$

and let $V_{0} \rightarrow \infty$. We then have that

$$
\lim _{V_{0} \rightarrow \infty}\left(\frac{d \pi_{m}}{d \alpha_{m}} \widetilde{U}\left[\mu_{P}+Z, \sigma^{2}\left(\omega_{m}\right)\right]+\sum_{x \neq m} \frac{d \pi_{x}}{d \alpha_{m}} \widetilde{U}\left[\mu_{P}+\alpha_{m} Q_{x}, \sigma^{2}\left(\omega_{m}\right)\right]\right)=\infty
$$

whereas $\lim _{V_{0} \rightarrow \infty} \pi_{m} \widetilde{U}_{1}\left[\mu_{P}+Z, \sigma^{2}\left(\omega_{m}\right)\right] V_{0}=0$ and $\lim _{V_{0} \rightarrow \infty} \sum_{x \neq m} \pi_{x} \widetilde{U}_{1}\left[\mu_{P}+\alpha_{m} Q_{x}, \sigma^{2}\left(\omega_{m}\right)\right] Q_{x}$ is a constant. ${ }^{12}$ There must therefore exist a $\overline{V_{0}}$ such that for all $V_{0}>\overline{V_{0}}$. As a result, $A>0$ for all $V_{0}>\overline{V_{0}} \cdot{ }^{13}$ This allows us to state our second proposition.

Proposition 2 If $\frac{\partial \pi_{m}}{\partial \alpha_{m}}>0$ and $V_{0}>\overline{V_{0}} \geq 0$, then managers who have career concerns will over invest in their company's stocks so that $\omega_{m}<\frac{\sigma_{F}^{2}-\sigma_{F P}}{\sigma_{P}^{2}+\sigma_{F}^{2}-2 \sigma_{F P}}$.

The two conditions necessary for $\omega_{m}<\frac{\sigma_{F}^{2}-\sigma_{F P}}{\sigma_{P}^{2}+\sigma_{F}^{2}-2 \sigma_{F P}}$ make intuitive sense. First, it must be that the manager believes that owning shares has an impact on his probability of being appointed CEO. This is the point of the paper. If the manager's investment in his firm has no impact his probability of becoming CEO, then the model is moot. The second condition is more problematic, but from an economic point of view, we may presume that corporations are large enough to guarantee that $V_{0}>\overline{V_{0}}$.

As a result the first order condition tells us that a manager will over-invest in his firm's stock if he believes that he has a chance to be appointed CEO of the company in the event that the incumbent CEO leaves. This means that any manager who thinks that being a "good citizen of the corporation" increases his expected payoff from becoming CEO will accumulate shares in the corporation even if that is contrary to an efficient portfolio management diversification strategy.

\footnotetext{
${ }^{12}$ To see why, apply the l'Hôpital rule to $\lim _{V_{0} \rightarrow \infty} \widetilde{U}_{1}\left[\mu_{P}+Z, \sigma^{2}\left(\omega_{m}\right)\right] V_{0}$, we find that $\lim _{V_{0} \rightarrow \infty} \widetilde{U}_{11}\left[\mu_{P}+Z, \sigma^{2}\left(\omega_{m}\right)\right]=0$.

${ }^{13}$ It is possible that $\overline{V_{0}}=0$, so that $A>0$ for any firm value. For example, if $Q_{m}=Q_{x}=0$ for all $x$. Then

$$
A=\frac{d \pi_{m}}{d \alpha_{m}} \widetilde{U}\left[\mu_{P}+G, \sigma^{2}\left(\omega_{m}\right)\right]+\sum_{x \neq m} \frac{d \pi_{x}}{d \alpha_{m}} \widetilde{U}\left[\mu_{P}, \sigma^{2}\left(\omega_{m}\right)\right]>0
$$
}

holds trivially because $G>0$. 


\subsection{Model Predictions}

The first order condition allows us to make predictions as to the impact of the parameters of the model. Let us rewrite the implicit solution to the first order condition as:

$$
\Theta=\left(1-\omega_{m}\right)-\frac{\sigma_{P}^{2}-\sigma_{F P}}{\sigma_{P}^{2}+\sigma_{F}^{2}-2 \sigma_{F P}}+\frac{\rho W_{m}}{V_{0}} \frac{A / 2 B}{\sigma_{P}^{2}+\sigma_{F}^{2}-2 \sigma_{F P}}=0
$$

where, as before,

$$
\begin{aligned}
A= & \frac{d \pi_{m}}{d \alpha_{m}} \widetilde{U}\left[\mu_{P}+Z, \sigma^{2}\left(\omega_{m}\right)\right]-\pi_{m} \widetilde{U}_{1}\left[\mu_{P}+Z, \sigma^{2}\left(\omega_{m}\right)\right] V_{0} \\
& +\sum_{x \neq m} \frac{d \pi_{x}}{d \alpha_{m}} \widetilde{U}\left[\mu_{P}+\alpha_{m} Q_{x}, \sigma^{2}\left(\omega_{m}\right)\right]+\sum_{x \neq m} \pi_{x} \widetilde{U}_{1}\left[\mu_{P}+\alpha_{m} Q_{x}, \sigma^{2}\left(\omega_{m}\right)\right] Q_{x}
\end{aligned}
$$

and

$$
\begin{aligned}
B= & (1-\rho) \widetilde{U}_{2}\left[\mu_{P}, \sigma^{2}\left(\omega_{m}\right)\right]+\rho \pi_{m} \widetilde{U}_{2}\left[\mu_{P}+Z, \sigma^{2}\left(\omega_{m}\right)\right] \\
& +\rho \sum_{x \neq m} \pi_{x} \widetilde{U}_{2}\left[\mu_{P}+\alpha_{m} Q_{x}, \sigma^{2}\left(\omega_{m}\right)\right]
\end{aligned}
$$

Recall that $Z=G+\left(\alpha^{*}-\alpha_{m}\right)\left(V_{0}+Q_{m}\right)+\alpha_{m} Q_{m}$. Also, we shall let $\frac{A}{2 B}<0$ so that managerial career concerns increase the proportion of any manager's wealth invested in the firm's stock.

We are then able to make a series of predictions associated with the ownership of the managers. Using the total derivative of (5), we can say $\frac{\partial \Theta}{\partial \delta} d \delta+\frac{\partial \Theta}{\partial\left(1-\omega_{m}\right)} d\left(1-\omega_{m}\right)$ for all the possible parameters $\delta$. This allows us to write $\frac{d\left(1-\omega_{m}\right)}{d \delta}=-\frac{\partial \Theta / \partial \delta}{\partial \Theta / \partial\left(1-\omega_{m}\right)}$ for any parameter $\delta$. Clearly, we need $\partial \Theta / \partial\left(1-\omega_{m}\right)>0$ so that the choice of $\omega_{m}$ that solves (5) maximizes the manager's utility. ${ }^{14}$ This means that the $\operatorname{sign}\left(\frac{d\left(1-\omega_{m}\right)}{d \delta}\right)=\operatorname{sign}\left(-\frac{\partial \Theta}{\partial \delta}\right)$.

- Prediction $\boldsymbol{\rho}$. The greater is the probability that the incumbent CEO quits, the more will the manager invest in his firm's stock. In other words $\frac{d\left(1-\omega_{m}\right)}{d \rho}>0$. To see why, note that $\operatorname{sign}\left(\frac{d\left(1-\omega_{m}\right)}{d \rho}\right)=\operatorname{sign}\left(-\frac{\partial \Theta}{\partial \rho}\right)=\operatorname{sign}\left(-\frac{W_{m}}{V_{0}} \frac{A / 2 B}{\sigma_{P}^{2}+\sigma_{F}^{2}-2 \sigma_{F P}}\right)>0$.

- Prediction G. The greater is the fixed benefits from becoming CEO, the more will the manager invest in his firm's stock. In other words $\frac{d\left(1-\omega_{m}\right)}{d G}>0$. To see why, note that $-\frac{\partial \Theta}{\partial G}=-\frac{\partial \Theta}{\partial A} \frac{\partial A}{\partial G}$. Expanding the terms, we find

$$
-\frac{\partial \Theta}{\partial G}=\left(\frac{-\frac{\rho W_{m}}{2 B V_{0}}}{\sigma_{P}^{2}+\sigma_{F}^{2}-2 \sigma_{F P}}\right)\left(\frac{d \pi_{m}}{d \alpha_{m}} \widetilde{U}_{1}\left[\mu_{P}+Z, \sigma^{2}\left(\omega_{m}\right)\right]-\pi_{m} \widetilde{U}_{11}\left[\mu_{P}+Z, \sigma^{2}\left(\omega_{m}\right)\right] V_{0}\right)
$$

which is positive since $B<0$. Thus we have the desired result.

\footnotetext{
${ }^{14}$ In other words the second order condition is of the correct sign: $\partial^{2} E U / \partial\left(\omega_{m}\right)^{2}<0$. Note that $\partial^{2} E U / \partial\left(\omega_{m}\right)^{2}=$ $\partial \Theta / \partial \omega_{m}=-\partial \Theta / \partial\left(1-\omega_{m}\right)$.
} 
- Prediction $\mathbf{Q}_{\mathbf{m}}$. The greater is the manager's quality, the more will the manager invest in his firm's stock. In other words $\frac{d\left(1-\omega_{m}\right)}{d Q_{m}}>0$. To see why, note that

$$
-\frac{\partial \Theta}{\partial Q_{m}}=\left(\frac{-\frac{\rho W_{m}}{2 B V_{0}}}{\sigma_{P}^{2}+\sigma_{F}^{2}-2 \sigma_{F P}}\right)\left(\begin{array}{c}
\frac{d \pi_{m}}{d \alpha_{m}} \widetilde{U}_{1}\left[\mu_{P}+Z, \sigma^{2}\left(\omega_{m}\right)\right] \alpha^{*} \\
-\pi_{m} U_{11}\left[\mu_{P}+Z, \sigma^{2}\left(\omega_{m}\right)\right] V_{0} \alpha^{*}
\end{array}\right)
$$

which is positive since $B<0$. Thus we have the desired result.

- Prediction $\alpha^{*}$. The greater is the target level of CEO ownership, the more will the manager invest in his firm's stock. In other words $\frac{d\left(1-\omega_{m}\right)}{d \alpha^{*}}>0$. To see why, note that $-\frac{\partial \Theta}{\partial \alpha^{*}}=-\frac{\partial \Theta}{\partial A} \frac{\partial A}{\partial \alpha^{*}}$. Expanding the terms, we find

$$
\frac{\partial \Theta}{\partial \alpha^{*}}=\left(\begin{array}{c}
-\frac{\rho W_{m}}{2 B V_{0}} \\
\sigma_{P}^{2}+\sigma_{F}^{2}-2 \sigma_{F P}
\end{array}\right)\left(\begin{array}{c}
\frac{d \pi_{m}}{d \alpha_{m}} \widetilde{U}_{1}\left[\mu_{P}+Z, \sigma^{2}\left(\omega_{m}\right)\right] \\
-\pi_{m} \widetilde{U}_{11}\left[\mu_{P}+Z, \sigma^{2}\left(\omega_{m}\right)\right] V_{0}
\end{array}\right)\left(V_{0}+Q_{m}\right)
$$

which is positive since $B<0$ and $V_{0}$ is much larger than $Q_{m}$. Thus we have the desired result.

- Prediction $\mathbf{W}_{\mathbf{m}}$. The greater is the manager's endowed wealth, the more will he invest in his firm's stock. In other words $\frac{d\left(1-\omega_{m}\right)}{d W_{m}}>0$. To see why, note that $-\frac{\partial \Theta}{\partial W_{m}}=-\left(\frac{\partial \Theta}{\partial W_{m}}+\frac{\partial \Theta}{\partial A} \frac{\partial A}{\partial W_{m}}\right)$. The first term is clearly negative since

$$
\frac{\partial \Theta}{\partial W_{m}}=\frac{\rho}{V_{0}} \frac{A / 2 B}{\sigma_{P}^{2}+\sigma_{F}^{2}-2 \sigma_{F P}}
$$

$\frac{\partial \Theta}{\partial A} \frac{\partial A}{\partial W_{m}}$ is also negative because

$$
\frac{\partial \Theta}{\partial A}=\left(\frac{\rho W_{m}}{V_{0}} \frac{1 / 2 B}{\sigma_{P}^{2}+\sigma_{F}^{2}-2 \sigma_{F P}}\right)<0
$$

and

$$
\frac{\partial A}{\partial W_{m}}=\left(\frac{d \pi_{m}}{d \alpha_{m}} \widetilde{U}_{1}\left[\mu_{P}+Z, \sigma^{2}\left(\omega_{m}\right)\right]+\sum_{x \neq m} \frac{d \pi_{x}}{d \alpha_{m}} \widetilde{U}_{1}\left[\mu_{P}+\alpha_{m} Q_{x}, \sigma^{2}\left(\omega_{m}\right)\right]\right) \frac{\partial Z}{\partial W_{m}}>0
$$

To see why, note that $\widetilde{U}_{1}\left[\mu_{P}+Z, \sigma^{2}\left(\omega_{m}\right)\right]<\widetilde{U}_{1}\left[\mu_{P}+\alpha_{m} Q_{x}, \sigma^{2}\left(\omega_{m}\right)\right]$ and that $\frac{d \pi_{m}}{d \alpha_{m}}=$ $-\sum_{x \neq m} \frac{d \pi_{x}}{d \alpha_{m}}>0$. Also, clearly, we also have that $\frac{\partial Z}{\partial W_{m}}=\frac{\partial Z}{\partial \alpha_{m}} \frac{\partial \alpha_{m}}{\partial W_{m}}=-\left(1+\frac{\bar{Q}}{V_{0}}\right)\left(1-\omega_{m}\right)<$ 0 .

- Prediction $\frac{\mathrm{d} \pi_{m}}{\mathrm{~d} \boldsymbol{\alpha}_{m}}$. The greater the impact of ownership on the probability of being named $\mathrm{CEO}$, the more will the manager invest in his firm's stock because it increases the expected value of the prize. In other words $\frac{d\left(1-\omega_{m}\right)}{d\left(\frac{d \pi_{m}}{d \alpha_{m}}\right)}>0$. To see why, note that

$$
\frac{\partial \Theta}{\partial\left(\frac{d \pi_{m}}{d \alpha_{m}}\right)}=\left(\frac{-\frac{\rho W_{m}}{2 B V_{0}}}{\sigma_{P}^{2}+\sigma_{F}^{2}-2 \sigma_{F P}}\right)\left(\widetilde{U}\left[\mu_{P}+Z, \sigma^{2}\left(\omega_{m}\right)\right]-\widetilde{U}\left[\mu_{P}+\alpha_{m} Q_{x}, \sigma^{2}\left(\omega_{m}\right)\right]\right)
$$


which is positive since $B<0$ and $Z$ is much larger than $\alpha_{m} Q_{x}$ for all $x$. Thus we have the desired result. This prediction may be interpreted as saying that if the company is not likely to appoint an insider, then managers will not have much influence on their nomination to the $\mathrm{CEO}$ position so that there is less need to over-invest in the company's stock.

- Prediction $\mathbf{V}_{\mathbf{0}}$. The greater is the value of the corporation, the less will the managers over-invest in the stock. In other words $\frac{d\left(1-\omega_{m}\right)}{d V_{0}}<0$. To see why, note that $\operatorname{sign}\left(-\frac{\partial \Theta}{\partial V_{0}}\right)=$ $\operatorname{sign}\left(\frac{\partial \frac{A}{V_{0}}}{\partial V_{0}}\right)$. As the size of the corporation increases, we know that $A \rightarrow \infty$. We also know that $\frac{1}{V_{0}} \rightarrow 0$. To see whether $A$ goes to infinity slower than $V_{0}$, we shall use the l'Hôpital rule. We then find that ${ }^{15}$

$$
\frac{\lim _{V_{0} \rightarrow \infty} \frac{\partial A}{\partial V_{0}}}{\lim _{V_{0} \rightarrow \infty} \frac{\partial V_{0}}{\partial V_{0}}}=\lim _{V_{0} \rightarrow \infty} \frac{\partial A}{\partial V_{0}}=0
$$

So that the larger is the corporation in terms of value, the less will managers over-invest in it.

- Prediction $\boldsymbol{\sigma}_{F}^{2}$. The more volatile the firm's stock is, the less will the manager over-invest in it. In other words $\frac{d\left(1-\omega_{m}\right)}{d \sigma_{F}^{2}}<0$. To see why, note that

$$
-\frac{\partial \Theta}{\partial \sigma_{F}^{2}}=-\left(\begin{array}{c}
\left(\sigma_{P}^{2}-\sigma_{F P}\right)+\frac{\rho W_{m}}{V_{0}} \frac{\partial(A / 2 B)}{\partial \sigma_{F}^{2}} \\
-\left(\frac{\rho W_{m}}{V_{0}}\right)\left(\frac{A}{2 B}\right)\left(\sigma_{P}^{2}+\sigma_{F}^{2}-2 \sigma_{F P}\right)
\end{array}\right)\left(\begin{array}{c}
1 \\
\sigma_{P}^{2}+\sigma_{F}^{2}-2 \sigma_{F P}
\end{array}\right)^{2}
$$

A sufficient condition for this to be negative is $\frac{\partial(A / 2 B)}{\partial \sigma_{F}^{2}}>0$. This occurs when $\frac{\partial(A / 2 B)}{\partial \sigma_{F}^{2}}=$ $\frac{1}{2 B^{2}}\left(\frac{\partial A}{\partial \sigma_{F}^{2}} B-\frac{\partial B}{\partial \sigma_{F}^{2}} A\right)>0$, so that it is sufficient to show that $\frac{\partial A}{\partial \sigma_{F}^{2}}<0$ and $\frac{\partial B}{\partial \sigma_{F}^{2}}>0$ to be done. Writing $\frac{\partial A}{\partial \sigma_{F}^{2}}$ and $\frac{\partial B}{\partial \sigma_{F}^{2}}$, we find

$$
\begin{aligned}
\frac{\partial A}{\partial \sigma_{F}^{2}}= & \frac{d \pi_{m}}{d \alpha_{m}} \widetilde{U}_{2}\left[\mu_{P}+Z, \sigma^{2}\left(\omega_{m}\right)\right]\left(1-\omega_{m}\right)^{2} \\
& -\pi_{m} \widetilde{U}_{12}\left[\mu_{P}+Z, \sigma^{2}\left(\omega_{m}\right)\right] V_{0}\left(1-\omega_{m}\right)^{2} \\
& +\sum_{x \neq m} \frac{d \pi_{x}}{d \alpha_{m}} \widetilde{U}_{2}\left[\mu_{P}+\alpha_{m} Q_{x}, \sigma^{2}\left(\omega_{m}\right)\right]\left(1-\omega_{m}\right)^{2} \\
& +\sum_{x \neq m} \pi_{x} \widetilde{U}_{12}\left[\mu_{P}+\alpha_{m} Q_{x}, \sigma^{2}\left(\omega_{m}\right)\right] Q_{x}\left(1-\omega_{m}\right)^{2}
\end{aligned}
$$

using the same argument we used to argue that $A>0$ (i.e., letting $Q_{m}=Q_{x}=0$ for all $x$ and $V_{0}$ is very large), we can show that $\frac{\partial A}{\partial \sigma_{F}^{2}}<0$ because $\widetilde{U}_{2}\left[\mu_{P}+Z, \sigma^{2}\left(\omega_{m}\right)\right]<0$. We also

\footnotetext{
${ }^{15}$ To see why, consider that$$
\frac{\partial A}{\partial V_{0}}=\left(\frac{d \pi_{m}}{d \alpha_{m}} \widetilde{U_{1}}\left[\mu_{P}+Z, \sigma^{2}\left(\omega_{m}\right)\right]-\pi_{m} \widetilde{U}_{11}\left[\mu_{P}+Z, \sigma^{2}\left(\omega_{m}\right)\right] V_{0}\right)\left(\alpha^{*}-\alpha_{m}\right)-\pi_{m} \widetilde{U}_{1}\left[\mu_{P}+Z, \sigma^{2}\left(\omega_{m}\right)\right]
$$

Since $\lim _{V_{0} \rightarrow \infty} \widetilde{U_{1}}[\bullet]=\lim _{V_{0} \rightarrow \infty} \widetilde{U_{11}}[\bullet]=\lim _{V_{0} \rightarrow \infty} \widetilde{U}_{11}[\bullet] V_{0}=0$, is it clear that $\lim _{V_{0} \rightarrow \infty} \frac{\partial A}{\partial V_{0}}=0$.
} 
find that

$$
\begin{aligned}
\frac{\partial B}{\partial \sigma_{F}^{2}}= & (1-\rho) \widetilde{U}_{22}\left[\mu_{P}, \sigma^{2}\left(\omega_{m}\right)\right]\left(1-\omega_{m}\right)^{2}+\rho \pi_{m} \widetilde{U}_{22}\left[\mu_{P}+Z, \sigma^{2}\left(\omega_{m}\right)\right]\left(1-\omega_{m}\right)^{2} \\
& +\rho \sum_{x \neq m} \pi_{x} \widetilde{U}_{22}\left[\mu_{P}+\alpha_{m} Q_{x}, \sigma^{2}\left(\omega_{m}\right)\right]\left(1-\omega_{m}\right)^{2}
\end{aligned}
$$

Here, by assumption of the utility function, we have that $\widetilde{U}_{22}>0$. This means that $\frac{\partial B}{\partial \sigma_{F}^{2}}>0$ for all parameter values. It follows that $\frac{\partial A}{\partial \sigma_{F}^{2}} B-\frac{\partial B}{\partial \sigma_{F}^{2}} A$ because $B<0$, so that $\frac{d\left(1-\omega_{m}\right)}{d \sigma_{F}^{2}}<0$.

The two following tables summarize the predictions of our model.

\begin{tabular}{|c|c|}
\hline \multicolumn{2}{|c|}{ Table 1A. Summary of the model's predictions on CEO appointment } \\
\begin{tabular}{|c|c|}
\hline Prediction & Meaning \\
\hline$\frac{d \pi_{m}}{d Q_{m}}>0$ & A manager is more likely to be appointed CEO when: \\
\hline$\frac{d \pi_{m}}{d \alpha_{m}}>0$ & His managerial ability is greater \\
\hline
\end{tabular} \\
\hline
\end{tabular}

\begin{tabular}{|} 
Table 1B. Summary of the model's predictions on portfolio allocation \\
\begin{tabular}{|c|c|}
\hline Prediction & $\begin{array}{c}\text { Meaning } \\
\text { The manager is more likely to invest in the firm's } \\
\text { stock because of career concerns when: }\end{array}$ \\
\hline$\frac{d\left(1-\omega_{m}\right)}{d \rho}>0$ & The probability of the CEO leaving is higher \\
\hline$\frac{d\left(1-\omega_{m}\right)}{d G}>0$ & The fixed benefit of becoming CEO is larger \\
\hline$\frac{d\left(1-\omega_{m}\right)}{d Q_{m}}>0$ & His managerial ability is greater \\
\hline$\frac{d\left(1-\omega_{m}\right)}{d \alpha^{*}}>0$ & The target ownership of the CEO is higher \\
\hline$\frac{d\left(1-\omega_{m}\right)}{d W_{m}}>0$ & The wealthier is the manager. \\
\hline$\frac{d\left(1-\omega_{m}\right)}{d\left(\frac{d \pi_{m}}{d \alpha_{m}}\right)}>0$ & The manager's ability to influence his nomination is greater \\
\hline$\frac{d\left(1-\omega_{m}\right)}{d V_{0}}<0$ & The corporation is smaller \\
\hline$\frac{d\left(1-\omega_{m}\right)}{d \sigma_{F}^{2}}<0$ & The firm's stock volatility is smaller \\
\hline
\end{tabular} \\
\hline
\end{tabular}

\section{The Sample}

Our basic data source is the widely used Standard and Poor's ExecuComp, which contains data on the compensation of the top-five executives during 1992-2002 at each of the firms in S\&P 500, S\&P Midcap 400, S\&P SmallCap 600 and also 817 companies not trading on a major S\&P index. Because the data is more complete starting in 1993 due to enhanced SEC regulation and because we need to lag variables one period, we restrict our analysis to the years 1993-2002. 
To identify new CEO appointments we use ExecuComp's variable "becamece", which contains the date at which an executive becomes CEO. ${ }^{16}$ We identify 2,828 firm-years where the date contained in "becamece" is in the period 1993-2002. We then drop 1,296 cases due to inconsistencies in the ExecuComp data, which are likely to be false CEO replacements. A vast majority of these cases arises because the variable "becomece" records a new CEO identity in a given year, but the same executive held the CEO flag during previous years. Thus, we eliminate cases that are highly unlikely to be true CEO replacements and very likely to be data errors. Of the remaining 1,532, we drop 372 cases where the required ownership data was missing. Specifically, for the departing CEO and insiders (whether appointed CEO or not), we require non-missing ownership data for the year preceding the appointment and, for those executives that do not leave the company, we require data on the year of the appointment and the year after the appointment. For CEOs appointed from outside the firm, we require non-missing ownership data for the appointment year, and for the following year if they stay in the company. We also drop 35 cases where we have data on less than two non-CEO insiders the year preceding the new CEO appointment. We do this to make sure that there is really competition for the CEO position. For example, if there is only one non-CEO executive, he will be the only possible successor and the choice of the replacement is trivial (unless an outsider is being considered for the position as well). In such a case, we would not expect to see any of the action implied by our hypotheses. However, it could also be that there are really more than one non-CEO executive, but the data is missing in the database. Given that there are only 35 cases, we decide to drop them (but our results are similar if we keep these cases in the sample). We further drop two cases where more than one CEO was appointed in a given year. These excluded cases are likely to arise when there is a temporary CEO appointment until the new CEO takes charge of the company, and thus could confound the effects we intend to explore. Thus, our final sample consists of 1,123 firm-years with clean cases of new CEO appointments during 1993-2002. In addition, for every CEO appointment case we search across firm executives to identify ex-CEOs that stay in the company but are not appointed again. We assume that these executives do not aspire to become CEO again, and we drop them from the sample (99 executive-year observations).

Table $2 \mathrm{~A}$ shows the structure of our sample. Date $\mathrm{t}$ is the year of the new CEO appointment, and so dates $t-1$ and $t+1$ denote the year before and after the replacement. The table classifies the executives in our sample into Departing CEOs, New CEOs, and Non-Appointed Top Managers. The first category simply refers to CEOs leaving office at date t. The second consists of executives appointed CEOs at date t, and it is in turn divided into Insiders and Outsiders, according to whether the appointed executive is an insider or is hired from outside the firm. The third consists of firm insiders that where not appointed CEOs at date t, and is divided into Strong Candidates,

\footnotetext{
${ }^{16}$ The database contains two other variables related to CEO identity. These are the current CEO flag (ceoann), and an annual CEO flag (pceo). All CEO identity variables contain missing information. We choose the variable with the least missing information, becamece, to identify changes in CEO identity.
} 
which have the highest ownership among all non-appointed managers, and Other Executives.

\section{Insert Table 2A here}

The table shows that 154 of the replaced CEOs leave the company in the same year they are replaced, while an additional 761 leave in the following year. Of the 1,123 CEO replacements, 781 $(70 \%)$ are insiders, while the rest are outsiders. The table also shows that non-appointed managers exhibit substantial departure rates in years surrounding the CEO replacement.

Table 2B shows the distribution of CEO replacements by industry, and distinguishes between inside and outside replacements. About half of the replacements in our sample occur in the manufacturing sector, and $70 \%$ of them involve inside appointments. However, the table shows considerable variation in the fraction of inside replacements across industries.

\section{Insert Table 2B here}

\section{Results}

\subsection{CEO appointment decisions and ex-ante managerial ownership}

The first set of predictions from the model discussed in Section 2 concerns the role of ex-ante managerial ownership in CEO appointment decisions. In our model, the cost to shareholders of aligning incentives with a new CEO is decreasing in the executive's prior ownership in the firm. This cost reaches a maximum when the appointed executive has no ownership in the firm, as is the case of outside CEO hires. Thus, we predict that, everything else constant,

1. Conditional on the decision to appoint an insider, the probability that any specific insider is appointed CEO is positively related to her ownership in the firm; and

2. An outsider is more likely to be appointed when the ownership of the insiders is very low, thus making outside executives with no ownership in the firm less costly relative to potential inside appointments.

We define fractional ownership of any given manager, alpha, as the number of shares held plus the number of shares related to unexercised stock options (vested and unvested) held as a percentage of shares outstanding. We start by exploring our first prediction about the relation between CEO appointment decisions and managerial ownership. Table 3 reports ownership of top-managers as of the year before the CEO replacement, and distinguishes those managers that are appointed CEOs from those that are not.

Insert Table 3 here 
In firms with inside replacements, the ownership of appointed managers more than doubles that of non-appointed managers at both the mean and the median, and these differences are statistically significant. The last column of the table shows that in firms with outside appointments, the ownership of the non-appointed insiders is similar to that of non-appointed executives in firms with inside replacements.

Figure 2 classifies all executives in firms with inside replacements into quintiles of managerial ownership, and shows the fraction of executives that were appointed CEOs from each quintile.

\section{Insert Figure 2 here}

Consistent with the results in the previous table, Figure 2 shows that inside replacements are much more likely to be chosen from the two highest ownership quintiles. Notably, half of the executives in the top quintile are appointed CEOs. Thus, preliminary evidence supports our prediction that executives are more likely to be appointed CEOs when their ownership is higher. We now turn to the regression analysis.

Conditional on the decision to replace a CEO with an insider, we estimate Probit models of the probability that a particular insider is appointed CEO as a function of her ownership stake in the firm and control variables, both recorded the year preceding the appointment decision. We use three different measures of the importance of managerial ownership in CEO appointment decisions. First, we use $\ln (1+a l p h a)$. Second, to capture the notion that the choice among insiders depends on the relative costs of providing them with optimal incentives, we define two additional variables. Devalpha is the difference between $\ln (1+a l p h a)$ for an executive and its median value across all the executives in the firm (other than the departing CEO). Maxowner equals one if the executive has the highest ownership among all executives (other than the departing CEO). Ideally, we need to control for other executive-specific factors that affect the appointment decision. In particular, these decisions are affected by the board's perception of managerial talent and experience, which are unobservable to us. As we lack detailed data on each executive's characteristics, we attempt to control for executive-specific factors using each executive's cash compensation and her tenure in the firm, both of which are correlated with talent and the importance of their role in the firm. Table 4 reports the marginal effects of the Probit models, which are estimated using the sample of firms with inside replacements. ${ }^{17}$

\section{Insert Table 4 here}

The results show that higher ownership substantially increases an executive's likelihood of being appointed CEO for all specifications of the ownership variable. The results are economically

\footnotetext{
${ }^{17}$ The results are similar if we run the Probit models on the entire sample of replacements, including outside replacements, while controlling for factors that affect the inside versus outside replacement decision (e.g., industry adjusted return to shareholders and ROA). In this case, the dependent variable equals zero for all executives in firms with outside replacements. The results are available from the authors.
} 
significant. For example, Panel $\mathrm{C}$ shows that the executive with the highest ownership is $51 \%$ more likely to be appointed CEO than other insiders. Thus, the evidence supports our first prediction that, conditional on the decision to appoint an insider, an executive's chances of being appointed CEO increase in the size of her ownership stakes in the firm. To explore whether the effect of insider ownership on the probability of CEO appointment is non-linear, Table 5 reports the marginal effects of Probit models similar to those in the previous table, but where the ownership variable is replaced by ownership quintile dummy variables (quintile 1 is the omitted category in all regressions). While we still focus on firm-years with inside replacements, our results are similar if we include outside replacements and control for factors that affect the inside/outside replacement decision (results available from the authors).

\section{Insert Table 5 here}

The results confirm the findings in Table 4, and suggest a strong non-linearity in the effect of higher managerial ownership on the probability of CEO appointment. The fourth column of the table shows that insiders with ownership in quintiles 2, 3, 4 and 5 are $2.4 \%, 5.8 \%, 18.1 \%$, and $41.3 \%$ more likely to be appointed CEOs than insiders with ownership in the lowest quintile. Results are qualitatively similar if we construct the quintiles using Devalpha (the difference between $\ln (1+a l p h a)$ for an executive and its median value across all executives in the firm other than the departing CEO). Results are available from the authors.

To explore our second prediction that outsiders are more likely to be appointed at the CEO position when the ownership of the potential insider candidates is lower, we run a Probit model of the probability of an outside replacement as a function of insider ownership and a vector of control variables. Specifically, for each of the 1,123 CEO replacements in our sample, the dependent variable equals one if the newly appointed CEO is an outsider, and zero otherwise. Our test variable is $\operatorname{Max}(\operatorname{alpha})$, defined as the ownership level of the insider executive with the highest ownership (other than the departing CEO). Our previous results show that the insider with the highest ownership is the executive with highest chances of being appointed CEO. Thus, we use her ownership level as an inverse proxy for shareholder's cost of aligning her incentives with their own if appointed CEO relative to the cost of aligning incentives with a potential outside replacement. Thus, we expect that higher values of $\operatorname{Max}(a l p h a)$ will be associated with lower probabilities of outside appointments. As the board's decision between inside and outside replacements is driven in part by past firm performance (see Agrawal, Knoeber and Tsoulouhas, 2003, and Huson, Malatesta and Parrino, 2004), we control for industry-adjusted ROA and industry-adjusted return to shareholders. We also control for two factors related to the quality of potential insider replacements: the natural logarithm of cash compensation (salary plus bonus) corresponding to the insider with the highest cash compensation, Max(lnsalbon), and the tenure of the most experienced insider, Max(tenure). 
The computation of both of these variables excludes the departing CEO. All independent variables are lagged one year. Table 6 reports the marginal effects of the Probit models.

\section{Insert Table 6 here}

The coefficient on $\operatorname{Max}($ alpha) is negative and statistically significant in all six columns of the table. These results provide strong support for our prediction that outside replacements are less likely to occur when inside candidates have higher ownership stakes in the firm. In terms of the control variables, consistent with previous work we find that outside CEO replacements are more likely to occur when the firm is under-performing relative to industry peers. We also find a negative effect on the probability of outside CEO replacements arising from our proxies for insider ability, Max(lnsalbon) and Max(tenure). In addition, this suggests that our results on Max(alpha) are not driven by the correlation between the level of current compensation and accumulated ownership.

\subsection{Changes in insider ownership surrounding CEO turnover}

Our third prediction concerns the relation between changes in insider ownership and CEO replacements. Specifically, we argued that, when managers aspire to obtain the CEO position, optimal insider ownership is negatively related to the probability of a current CEO's departure. Right after an appointment decision, the likelihood that any of the non-appointed executives will be appointed CEO in the short run drops dramatically during or right after a CEO departure. Thus, our model predicts that non-appointed insiders will optimally reduce their ownership in the firm following a new CEO appointment. In addition, because the degree of overinvestment in the firm is positively related to a manager's quality, we expect the effect of reduced career opportunities on portfolio decisions to be stronger for managers with higher pre-event ownership. Table 7 reports the changes in ownership (changes in alpha) across executives the year of the actual CEO replacement (denoted date $\mathrm{t}$ ) and the year after (denoted date $\mathrm{t}+1$ ). Panel A reports ownership changes conditional on the decision to stay in the firm. The entries denoted "date t" exclude executives that left the company during date $t$, while the entries denoted "date $t+1$ " exclude executives that left the company at date $t+1$. In Panel B, we assume that executives that leave the firm sell all of their stockholding, and thus we compute their change in ownership as minus their ownership in the year preceding their departure.

\section{Insert Table 7 here}

Panel A shows that Departing CEOs substantially reduce their stakes in the firm, and most of them leave the company the year after their resignation. New insider CEOs exhibit large increases in ownership in the year of their appointment, and in subsequent years. The increase in ownership of new insider CEOs is much larger than that of non-appointed managers, which is consistent with 
shareholders granting new shares to new CEOs to achieve optimal incentive alignment. The last two columns show weak evidence that, among non-appointed managers, strong candidates (i.e., those with the highest ownership amount non-appointed managers) increase their ownership by less than other non-appointed executives. Interestingly, when we look at the mean change in ownership, strong candidates reduce their ownership while other executives increase it both in the year of the replacement and the year after. However, the data in Panel A excludes executive departures, and thus should be interpreted as an upper bound on the change in ownership. Panel B assumes that executives that leave the company sell all their stakes, and thus their change in ownership is $-a l p h a_{t-1}$. When executive departures are accounted for, the entire group of non-appointed managers exhibits reductions in ownership. In addition, the last two columns now show stark differences in the changes in managerial ownership among strong candidates and other managers. Specifically, strong candidates show substantially larger reductions in ownership than other nonappointed managers.

Thus, under the assumption that the effect of career concerns on managerial portfolio decisions is stronger for executives with higher ownership (because these executives are likely to have overinvested in the firm the most), the evidence in Table 7 is consistent with our prediction that decreases in the probability of CEO replacement lead managers with career concerns to sell their shares.

To further understand the behavior of managerial ownership surrounding CEO turnover, we estimate Probit models of the probability that a given executive will reduce her ownership during the year of the CEO replacement. Thus, our dependent variable equals one if the executive's change in ownership from date $t-1$ to date $t$ is negative, and zero otherwise. We restrict attention to insider executives that stay with their firms during the year of the new CEO appointment and exclude outside replacements. We classify each executive into one of four categories: Departing CEOs, New Insider CEOs, Strong Candidates, and Other Executives. Table 8 reports the marginal effects. New Insider CEOs (which never decreased their ownership) are the left-out category in all regressions. Thus, the coefficients on the remaining categories can be interpreted as the probability of reducing ownership.

\section{Insert Table 8}

The results are robust to controlling for shareholder returns, which can affect the decision to sell shares, and executive specific controls such as cash compensation and tenure. The table shows that all groups of executives reduce their ownership in the firm during the year in which CEO turnover occurs. Departing CEOs are the most likely to reduce their ownership, followed by Strong Candidates, and then by Other Executives. That CEOs stepping down are the most likely to sell their shares is not surprising. The most interesting result is that, consistent with the preliminary information in Table 7, Strong Candidates are much more likely to sell their shares than Other 
Executives (twice as likely, to be precise). This provides strong support for our prediction that non-appointed executives with the highest ownership among non-appointed managers are the ones whose career concerns play a more dramatic role in their portfolio decisions. Thus, the reduction in the probability of an opportunity to become CEO that occurs right after a new CEO replacement induces a stronger readjustment in the portfolios of managers with higher ownership in the firm.

We now refine our analysis and focus on the portfolio decisions of non-appointed managers in firms with both inside and outside replacements. Still, our main objective is to study how the level of an executive's ownership can explain her portfolio decisions following a new CEO appointment. As in previous tables, we run Probit models of the probability that an executive will reduce her ownership on measures of ex-ante ownership and a vector of control variables. We consider three alternative measures that capture the importance of each executive's ex-ante ownership in her decision to reduce her ownership in the firm. These are $\ln (1+$ alpha), Strong Candidate (a dummy variable indicating if the executive has the highest ownership among all non-appointed managers), and Devalpha, which is the difference between $\ln (1+a l p h a)$ for an executive and its median value across all executives of the firm (other than the departing CEO). Recall that we assume that the probability of an opportunity to become CEO falls dramatically for executives in firms that just replaced their CEO. In addition, we argue that outside replacements is even worse news that just not being chosen among the insider candidates. In such a case, outside appointments convey the information that the board does not perceive insiders as good candidates to become CEOs. Thus, this reduces an executive's perception of the probability of having an opportunity to become CEO substantially more than when the appointed CEO is an insider. To capture this idea, we define InsideCEO, a dummy variable equal to one if the firm appoints an insider, and zero otherwise. Thus, we expect a negative effect of InsideCEO on the probability that a particular executive will reduce her ownership stake in the firm. Finally, we control for the return to shareholders and each executive's cash compensation and tenure in the firm. Table 9 reports the estimated marginal effects.

\section{Insert Table 9 here}

The results show that higher ownership (whether we use its absolute level or its level in relation to other non-appointed managers) has statistically significant and positive effect on the probability that an executive will reduce her ownership. In addition, we also find a negative and statistically significant effect of InsideCEO on the likelihood of reductions in ownership. This supports our intuition that non-appointed managers perceive more damage on their career prospects when an outsider is appointed CEO instead of an insider, and thus are more likely to reduce their stakes in the firm. Basically, in the model, this can be interpreted as a reduction in the sensitivity of their probability of promotion of a manager to his ownership in the firm, given some probability of 
CEO departure. In other words, the results in Table 9 show that an outside appointment reduces a manager's influence of his probability of being appointed so that he reduces his financial stake in the corporation.

\subsection{Analysis of non-appointed executive departures}

One important decision for non-appointed managers that face less optimistic career prospects (i.e., reduced opportunities to compete for the CEO position) is whether to stay with the company or leave. As we argued in the previous section, if career concerns lead executives to choose ownership stakes in the firm that are too high compared their optimal level in the absence of career concerns, then non-appointed executives with higher ownership are those for which the reduced probability of competing in a contest to become CEO will induce a larger readjustment in their optimal portfolio. Another possibility is that executives that face reduced career opportunities may decide to leave the company. Although the model we developed in section 2 does not allow us to make this prediction, it may be easily modified to incorporate this possibility. Suppose, for example, that the executive remains with the firm only if his expected utility exceeds some threshold $U_{\min }$. The maximization problem (see equation 3) of the manager then becomes

$$
\begin{aligned}
\max _{\omega_{m}} E U= & (1-\rho) \widetilde{U}\left[\mu_{P}, \sigma^{2}\left(\omega_{m}\right)\right] \\
& +\rho \pi_{m}\left(q_{m}, q_{-m}, \alpha_{m}, \alpha_{-m}\right) \widetilde{U}\left[\mu_{P}+Z, \sigma^{2}\left(\omega_{m}\right)\right] \\
& +\rho \sum_{x \neq m} \pi_{x}\left(q_{x}, q_{-x}, \alpha_{x}, \alpha_{-x}\right) \widetilde{U}\left[\mu_{P}+\alpha_{m} Q_{x}, \sigma^{2}\left(\omega_{m}\right)\right]
\end{aligned}
$$

subject to the participation constraint $E U\left(\omega_{m}^{*}\right) \geq U_{\min }$. Suppose, for example, that

$$
U_{\min }=\widetilde{U}\left[\mu_{P}, \sigma^{2}\left(\frac{\sigma_{F}^{2}-\sigma_{F P}}{\sigma_{P}^{2}+\sigma_{F}^{2}-2 \sigma_{F P}}\right)\right]+C\left(Q_{m}\right)-K\left(\alpha_{m}\right)
$$

where $C\left(Q_{m}\right)$ is a measure of outside career opportunity that depends on the manager's quality with $C^{\prime}\left(Q_{m}\right)>0$ and $K\left(\alpha_{m}\right)$ is a function of the manager's unvested stock options that he must forego if he leaves the firm. Regarding $C\left(Q_{m}\right)$, it is logical to presume that a more qualified manager is more likely to find an interesting outside appointment than a less qualified manager. A manager whose career prospect at the firm is nil (because $\rho=0$ ) and whose outside opportunity is attractive (i.e., $C\left(Q_{m}\right)>0$ ) will choose to leave the firm rather than stay and invest his wealth is he does not need to forego too much unvested wealth. In other words, if a manager stays with the firm even though $\rho=0$, he will choose to invest a proportion $\omega_{m}=\frac{\sigma_{F}^{2}-\sigma_{F P}}{\sigma_{P}^{2}+\sigma_{F}^{2}-2 \sigma_{F P}}$ in the market portfolio. If his reservation utility is as $U_{\min }$ above and that $C\left(Q_{m}\right)-K\left(\alpha_{m}\right)>0$, then he will decide to leave the firm entirely. Thus there exists a $\rho_{\text {min }}>0$ so that the manager is indifferent between staying and leaving. As a new CEO is appointed, it may be that $\rho$ falls below this $\rho_{\min }$ so 
that it is optimal for the manager to leave the corporation altogether rather than just adjust his portfolio. $^{18}$

Because ownership in the corporation may be a signal of the manager's quality, we expect that the manager for whom the participation constraint will bind first is the one who has the higher ownership, compared to the other managers. In other words, the most likely managers to leave the firm should be those who have the highest $U_{\min }$, which means the managers who have the larger $Q_{m}$, relative to the other managers.

We run Probit models of the probability that one of the non-appointed executives will leave the company. The main explanatory variables include Devalpha (the difference between $\operatorname{Ln}(1+$ alpha) for an executive and its median value across all executives, other than the departing CEO), $L n(1+$ alpha $)$, InsideCEO, and Devalpha $*$ InsideCEO. We argue that what drives the decision to leave the company is not only the absolute level of an executive's ownership, but also her ownership relative to that of other non-appointed managers. Specifically, higher ownership may make departure more difficult for an executive with financial interest in the firm. One reason is that a large proportion of such ownership could be in the form of unvested restricted shares or stock options that executives typically have to forfeit if they leave the firm. Thus, we expect a negative effect of $\operatorname{Ln}(1+$ alpha $)$ on the probability of executive departure. On the other hand, Devalpha captures the ownership of an executive relative to that of the other competing managers. Managers whose ownership is substantially higher than that of other competing executives are more likely to be those that are more strongly affected by the reduced career prospects, and thus are more likely to leave the company. As a result, we expect a positive association between Devalpha and the probability of departure.

We argued before that outside CEO replacements may be associated with worse career prospects for insiders. Thus, we expect a negative relation between InsideCEO and the probability of insider departure. As this effect should be stronger for executives with high ownership relative to other executives, we add the interaction term Devalpha $*$ InsideCEO, and expect a negative effect on the probability of departure. We control for industry-adjusted return to shareholders and industryadjusted ROA, as executives may derive some career benefit from staying in a company that outperforms the industry benchmark. Finally, we control for cash compensation using $\ln ($ salary + bonus), and executive tenure in the firm. Table 10 reports the marginal effects of these Probit

\footnotetext{
${ }^{18} \mathrm{~A}$ possible interpretation is that the managers who are the more likely to leave are those that have a higher quality. In other words, the participation constraint is more likely to bind the greater is $Q_{m}$. To see why, note that, from the implicit solution of the first order condition (equation 5)

$$
-\frac{\partial^{2} \Theta}{\partial \rho \partial Q_{m}}=\left(\begin{array}{c}
-\frac{W_{m}}{2 B V_{0}} \\
\sigma_{P}^{2}+\sigma_{F}^{2}-2 \sigma_{F P}
\end{array}\right)\left(\begin{array}{c}
\frac{d \pi_{m}}{d \alpha_{m}} \widetilde{U}_{1}\left[\mu_{P}+Z, \sigma^{2}\left(\omega_{m}\right)\right] \alpha^{*} \\
-\pi_{m} U_{11}\left[\mu_{P}+Z, \sigma^{2}\left(\omega_{m}\right)\right] V_{0} \alpha^{*}
\end{array}\right)>0
$$

whereas $C^{\prime}\left(Q_{m}\right)>0$. This means that the impact of a reduction in the probability of the CEO leaving will reduce a manager's ownership in the firm more the wealthier he is and the more qualified he is. These two parameters are arguably the most positively related to the manager's investment in his firm.
} 
models.

\section{Insert Table 10 here}

Consistent with our expectations, we find a positive effect of Devalpha and a negative effect of $\ln (1+a l p h a)$ on the probability of executive departure, and both effects are statistically significant. This suggests that higher ownership levels can make executive departure more difficult, but that managers with higher ownership relative to other executives are more likely to experience the most severe damage on their career prospects and are more likely to leave the company. Also in line with our expectations, non-appointed executives are less likely to leave the company following an inside appointment than an outside appointment. In addition, the coefficient on the interaction term provides weak evidence that executives with higher ownership relative to other executives are less likely to leave when the firm appoints an insider than when it appoints an outsider. This is again consistent with the damage on career prospects been more severe for executives in firms with outside appointments.

Consistent with our results, Hayes, Oyer and Schaefer (2002) find a positive association between CEO turnover and non-CEO turnover, especially for outside replacements. However, they interpret their results as evidence that firms are run by management teams, which tend to be replaced as a whole or move together to another firm. While we believe that management teams can provide part of the explanation, we suggest an alternative explanation. In our view, the results can be explained, at least in part, by rational decisions of non-appointed managers who perceive bad career prospects if they stay in the firm and thus decide to try their fortunes in other companies. In the concluding section we argue that when all the results are taken together, our theory about career concerns provides a better explanation of our findings.

\section{Discussion of results}

First, conditional on the decision to appoint an insider as the new CEO, we find that insiders with higher ownership in the firm are more likely to be appointed. Second, conditional on the decision (necessity) to replace the incumbent CEO, we find that firms are less likely to appoint an outsider when inside candidates have higher financial involvement with the corporation. Third, we find that non-appointed executives with higher ownership in the firm are more likely to reduce their financial involvement in the firm following CEO turnover. Fourth, non-appointed managers with the higher ownership relative to other managers are more likely to leave the company. Fifth, ownership reductions and departure by non-appointed executives is exacerbated when a firm outsider is appointed to the CEO position.

An alternative hypothesis can explain some of our results: More talented insiders receive higher compensation and thus accumulate higher stakes in the firm. When a firm chooses a CEO replace- 
ment from the pool of insiders, those more talented will have the largest ownership stakes and will also be more likely to be appointed. When the CEO needs to be replaced, the presence of an insider with high ownership in the firm is associated with the availability of a talented inside replacement, and thus making outside replacements more likely. Thus, a positive association between managerial skill and ownership can explain our first two results. The difference between the two views is one of causality: whereas the managers in our model choose higher ownership if their quality is higher, the alternative view states that the board compensates talent with higher ownership. Although both views can explain our first two results (i.e., why managers who are appointed CEO have a higher ownership), the alternate view cannot explain our other empirical results. If the most talented executives have the highest ownership and career concerns play no role in managerial portfolio decisions following CEO replacement, why would the most talented non-appointed executives reduce their ownership in the firm (our third result)?; why would they be more likely to leave the company (our fourth result)?; and why would they respond more to outside replacements (our fifth result)?

Hayes, Oyer and Schaefer (2002) document a positive association between CEO turnover and non-CEO turnover, especially for outside CEO replacements. The authors suggest this is evidence that firms are managed by teams, and that all executives in a team are replaced simultaneously when a CEO is fired. Thus, management teams can partially explain our fourth result of a positive association between CEO turnover and non-CEO departures during outside replacements. However, why are insiders with higher ownership more likely to follow the CEO to another company than insiders with lower ownership? In addition, the hypothesis that a large portion of the management team is replaced is less likely to be valid when the replacement CEO is an insider. Still, we document that non-appointed executives with higher ownership are also more likely to leave the firm following inside CEO replacements, and not just outside replacements. Moreover, the management-in-team hypothesis cannot explain why some non-appointed managers choose to stay in the company after the CEO replacement but reduce their ownership (our third result).

\section{Conclusion}

The goal of this paper was to investigate the portfolio allocation behavior of non-CEO managers around the appointment of a new CEO. To do so, we model the portfolio choices by managers who must allocate their wealth between their firm's stock and the market portfolio. Managers choose their investment in the firm trading off their desire to reduce their exposure to non-diversifiable firm-specific risk and the positive effect that their ownership has on their chances of promotion. Our model yields several testable predictions relating insider ownership, the outcome of promotion contests, the choice between inside and outside CEO replacements, and executive departures. Some of our predictions are unique to our model, and thus allow us to empirically differentiate between our story and alternative explanations of the results. 
We test our model using a sample of 1,129 CEO replacements during 1993-2002 and find support for our predictions. Our analysis of CEO appointment decisions is based on then idea that higher ownership by managers reduces the cost to shareholders of their appointment as CEOs. Our analysis of changes in ownership and executive departures is based on the assumption that managers desiring the firm's CEO position receive bad news about the career prospects in the firm when they are not appointed.

The empirical results of the paper may be summarized in three points. First, it appears that a manager has a greater probability of being appointed CEO when he holds a greater proportion of the firm's shares and stock options. We find this suggestive that appointing an insider, whose incentives are already partially aligned with that of the shareholders, is less costly than appointing an outside manager. This result is similar to the handicapping assumption of Agrawal, Knoeber and Tsoulouhas (2003).

Our results suggest that because managers are more likely to be appointed CEO if they hold more stock and stock options, they will appear to behave as a good citizen of the corporation by hoarding these securities until such a time when they feel their chance of becoming CEO has passed and gone. The more prestigious the CEO position (either measured as total CEO compensation or as the asset size of the corporate empire), the more likely manager will hoard stock and stock options to increase the probability that she will, eventually, benefit from the CEO position prestige.

Our results also suggest that the dynamics of managerial ownership, especially of non-CEO executives, is related to how portfolio choices by managers depend on their changing career opportunities in the firm. However, we do recognize that numerous other forces also contribute to the complex process of determining managerial ownership. Among the most important, ownership reflects the tension between the incentive alignment induced by the board managerial and managerial preference. Managerial portfolio decisions about their investment in the firm may also send signals to investors about the current and future stock price.

Although the current paper's empirical analysis concentrated mainly on the portfolio optimization behavior of the firm's managers around the time when the incumbent CEO leaves the firm, further research could investigate the dynamics of managerial ownership at any other time period. In particular, it may be interesting to assess whether there are events that trigger a top manager's decision to reduce his financial stake in the corporation, independently of a CEO succession. 


\section{References}

1. Agrawal, A., C. R. Knoeber and T. Tsoulouhas (2003). Are Outsider Handicapped in CEO Successions? Mimeo, University of Alabama.

2. Berle, A., and G. Means (1932). The Modern Corporation and Private Property. Macmillan, New York.

3. Bognanno, M. L. (2001). Corporate Tournaments. Journal of Labor Economics, 19: 290-315.

4. Borokhovich, K. A., R. Parrino and T. Trapani (1996). Outside Directors and CEO Selection. Journal of Financial and Quantitative Analysis, 31: 337-355.

5. Cannella, A. A. and W. Shen (2001). So Close and Yet So Far: Promotion Versus Exit for CEO Heirs Apparent. Academy of Management Journal, 44: 252-270.

6. Chan, W. (1996). External Recruitment Versus Internal Promotion. Journal of Labor Economics, 14: 555-570.

7. Core, J., and W. Guay (1999). The Use of Equity Grants to Manage Optimal Equity Incentives. Journal of Accounting and Economics, 28: 151-184.

8. Gibbons, R., and M. Waldman (1999). Theory of Wage and Promotion Dynamics Inside Firms. Quarterly Journal of Economics, 114(4): 1321-58.

9. Gibbons, R., and M. Waldman (2003). Enriching a Theory of Wage and Promotion Dynamics Inside Firms. NBER Working Papers: 98492003

10. Hayes, R. M., P. Oyer and S. Schaefer (2002). Stability of Top Management Teams. Mimeo, University of Chicago.

11. Himmelberg, C. P., G. R. Hubbard, and D. Palia (1999). Understanding the Determinants of Managerial Ownership and the Link Between Ownership and Performance. Journal of Financial Economics, 53: 353-384.

12. Huson, M. R., P. H. Malatesta and R. Parrino (2004). Managerial Succession and Firm Performance. Journal of Financial Economics, Forthcoming.

13. Kole, S. R. (1997). The Complexity of Compensation Contracts. Journal of Financial Economics, 43: 79-104.

14. Lazear, E. P. and S. Rosen (1981). Rank Order Tournaments as an Optimum Labor Contract. Journal of Political Economy, 89: 841-864. 
15. Main, B. G., C. A. O'Reilly and J. Wade (1993). Top Executive Pay: Tournament or Teamwork. Journal of Labor Economics, 11: 606-628.

16. O'Reilly, C. A., B. G. Main and G. S. Chrystal (1988). CEO Compensation as Tournament and Social Comparison: A Tale of Two Theories. Administrative Science Quarterly, 33: 257-274.

17. Ofek, E., and D. Yermack (2000). Taking Stock: Equity-Based Compensation and the Eolution of Managerial Ownership. Journal of Finance, 55: 1367-1384.

18. Parrino, R. (1997). CEO Turnover and Outside Succession: A Cross-Sectional Analysis. Journal of Financial Economics, 46: 165-197.

19. Rob, R. and P. Zemsky (2002). Social Capital, Corporate Culture and Incentive Intensity. Rand Journal of Economics, 33.

20. Rosen, S. (1986). Prizes and Incentives in Elimination Tournaments. American Economic Review, 76: 701-716.

21. Tirole, J. (1988). The Theory of Industrial Organization. MIT Press, Cambridge, MA.

22. Tsoulouhas, T., C. R. Knoeber and A. Agrawal (2003). Contests to Become CEO. Mimeo, North Carolina State University.

23. Vancil, R. F. (1987). Passing the Baton. Harvard Business School Press, Cambridge, MA.

24. Waldman, M. (2003). Ex Ante Versus Ex Post Optimal Promotion Rules: The Case of Internal Promotion. Economic Inquiry, 41: 27-41.

25. Weisbach, M. S. (1988). Outside Directors and CEO Turnover. Journal of Financial Economics, 20: 431-460. 


\section{Appendix A: Proofs.}

Proof of theorem 1. Given that $\alpha_{m}=\left(1-\omega_{m}\right) \frac{W_{m}}{V_{0}}$, the first order condition to (3) is

$$
\begin{aligned}
\frac{\partial E U}{\partial \omega_{m}}= & (1-\rho) \widetilde{U}_{2}\left[\mu_{P}, \sigma^{2}\left(\omega_{m}\right)\right]\left(2 \omega_{m} \sigma_{P}^{2}-2\left(1-\omega_{m}\right) \sigma_{F}^{2}+2\left(1-2 \omega_{m}\right) \sigma_{F P}\right) \\
& +\rho \frac{d \pi_{m}}{d \alpha_{m}}\left(-\frac{W_{m}}{V_{0}}\right) \widetilde{U}\left[\mu_{P}+Z, \sigma^{2}\left(\omega_{m}\right)\right] \\
& +\rho \pi_{m} \widetilde{U}_{1}\left[\mu_{P}+Z, \sigma^{2}\left(\omega_{m}\right)\right]\left(-V_{0}\right)\left(-\frac{W_{m}}{V_{0}}\right) \\
& +\rho \pi_{m} \widetilde{U}_{2}\left[\mu_{P}+Z, \sigma^{2}\left(\omega_{m}\right)\right]\left(2 \omega_{m} \sigma_{P}^{2}-2\left(1-\omega_{m}\right) \sigma_{F}^{2}+2\left(1-2 \omega_{m}\right) \sigma_{F P}\right) \\
& +\rho \sum_{x \neq m} \frac{d \pi_{x}}{d \alpha_{m}}\left(-\frac{W_{m}}{V_{0}}\right) \widetilde{U}\left[\mu_{P}+\alpha_{m} Q_{x}, \sigma^{2}\left(\omega_{m}\right)\right] \\
& +\rho \sum_{x \neq m} \pi_{x} \widetilde{U}_{1}\left[\mu_{P}+\alpha_{m} Q_{x}, \sigma^{2}\left(\omega_{m}\right)\right]\left(Q_{x}\right)\left(-\frac{W_{m}}{V_{0}}\right) \\
& +\rho \sum_{x \neq m} \pi_{x} \widetilde{U}_{2}\left[\mu_{P}+\alpha_{m} Q_{x}, \sigma^{2}\left(\omega_{m}\right)\right]\left(2 \omega_{m} \sigma_{P}^{2}-2\left(1-\omega_{m}\right) \sigma_{F}^{2}+2\left(1-2 \omega_{m}\right) \sigma_{F P}\right)
\end{aligned}
$$

We can rewrite the first order condition as

$$
\begin{aligned}
\frac{\partial E U}{\partial \omega_{m}}= & \left(\begin{array}{c}
(1-\rho) \widetilde{U}_{2}\left[\mu_{P}, \sigma^{2}\left(\omega_{m}\right)\right] \\
+\rho \pi_{m} \widetilde{U}_{2}\left[\mu_{P}+Z, \sigma^{2}\left(\omega_{m}\right)\right] \\
+\rho \sum_{x \neq m} \pi_{x} \widetilde{U}_{2}\left[\mu_{P}+\alpha_{m} Q_{x}, \sigma^{2}\left(\omega_{m}\right)\right]
\end{array}\right) 2 \omega_{m}\left(\sigma_{P}^{2}+\sigma_{F}^{2}-2 \sigma_{F P}\right) \\
& +\left(\begin{array}{c}
(1-\rho) \widetilde{U}_{2}\left[\mu_{P}, \sigma^{2}\left(\omega_{m}\right)\right] \\
+\rho \pi_{m} \widetilde{U}_{2}\left[\mu_{P}+Z, \sigma^{2}\left(\omega_{m}\right)\right] \\
+\rho \sum_{x \neq m} \pi_{x} \widetilde{U}_{2}\left[\mu_{P}+\alpha_{m} Q_{x}, \sigma^{2}\left(\omega_{m}\right)\right]
\end{array}\right) 2\left(\sigma_{F P}-\sigma_{F}^{2}\right) \\
& -\rho\left(\frac{W_{m}}{V_{0}}\right)\left(\begin{array}{c}
\frac{d \pi_{m}}{d \alpha_{m}} \widetilde{U}\left[\mu_{P}+Z, \sigma^{2}\left(\omega_{m}\right)\right] \\
-\pi_{m} U_{1}\left[\mu_{P}+Z, \sigma^{2}\left(\omega_{m}\right)\right] V_{0}
\end{array}\right) \\
& -\rho\left(\frac{W_{m}}{V_{0}}\right)\left(\begin{array}{c}
\sum_{x \neq m} \frac{d \pi_{x}}{d \alpha_{m}} \widetilde{U}\left[\mu_{P}+\alpha_{m} Q_{x}, \sigma^{2}\left(\omega_{m}\right)\right] \\
+\sum_{x \neq m} \pi_{x} U_{1}\left[\mu_{P}+\alpha_{m} Q_{x}, \sigma^{2}\left(\omega_{m}\right)\right] Q_{x}
\end{array}\right)
\end{aligned}
$$

Rearranging the terms yields the desired result. 


\section{Appendix B: Tables and Figures}

\section{Table 2A \\ Sample Description}

The sample consists of 1,123 CEO replacements occurred during 1993-2002. The year in which the replacement takes place is denoted time $t$, so times $t-1$ and $t+1$ indicate the year before and the year after the replacement, respectively. The executives in our sample are classified as "Departing CEOs" (the CEO leaving office), "New CEOs", and "Non-Appointed Top Managers" (these executives are not CEOs at t-1 and are not appointed CEOs at time t). The New CEOs are further broken down into Insiders and Outsiders, depending on whether they work in the company at t-1 or not, respectively. The group of Non-Appointed Top Managers is decomposed into "Strong Candidates", which have the highest ownership among the nonappointed insiders in each firm, and Other Executives.

\begin{tabular}{|c|c|c|c|c|c|c|c|}
\hline \multirow[b]{2}{*}{ In firm at: } & \multirow{2}{*}{$\begin{array}{l}\text { Departing } \\
\text { CEOs }\end{array}$} & \multicolumn{3}{|c|}{ New CEOs } & \multirow{2}{*}{$\begin{array}{l}\text { Non-Appointed } \\
\text { Top Managers }\end{array}$} & \multirow{2}{*}{$\begin{array}{c}\text { Strong } \\
\text { Candidates* }\end{array}$} & \multirow{2}{*}{$\begin{array}{c}\text { Other } \\
\text { Executives }\end{array}$} \\
\hline & & All & Insiders & Outsiders & & & \\
\hline $\mathrm{t}-1$ & 1,123 & - & 781 & - & 3,651 & 1,129 & 2,522 \\
\hline $\mathrm{t}$ & 969 & 1,123 & 781 & 342 & 2,579 & 841 & 1,738 \\
\hline$t+1$ & 208 & 924 & 654 & 270 & 1,540 & 513 & 1,027 \\
\hline \multicolumn{8}{|c|}{ \# of Executive Departures } \\
\hline Date $t$ & 154 & - & 0 & - & 1,076 & 289 & 787 \\
\hline Date $t+1$ & 761 & 199 & 127 & 72 & 1,035 & 327 & 708 \\
\hline
\end{tabular}

* The number of strong candidates at $\mathrm{t}-1$ is greater than the \# of replacements because of ties in alpha $\mathrm{t}-1$ 
Table 2B

\section{CEO replacements by industry}

The sample consists of 1,123 CEO replacements occurred during 1993-2002, broken down by industry and whether the new CEO is an insider or an outsider.

\begin{tabular}{lrrr}
\hline Industry & \# of cases & $\%$ inside & $\%$ outside \\
\hline & & & \\
Agriculture, Forestry, and Fisheries & 4 & $75 \%$ & $25 \%$ \\
Mineral Industries & 40 & $83 \%$ & $18 \%$ \\
Construction Industries & 13 & $92 \%$ & $8 \%$ \\
Manufacturing & 529 & $70 \%$ & $30 \%$ \\
Transportation, Communications, and & & & \\
Utilities ${ }^{1}$ & 130 & $75 \%$ & $25 \%$ \\
Wholesale Trade & 37 & $70 \%$ & $30 \%$ \\
Retail Trade & 105 & $70 \%$ & $30 \%$ \\
Finance, Insurance, and Real Estate & 101 & $82 \%$ & $18 \%$ \\
Service Industries & 156 & $49 \%$ & $51 \%$ \\
Other non-classified industries ${ }^{2}$ & 8 & $75 \%$ & $25 \%$ \\
& & & \\
Total \# of cases & 1,123 & $70 \%$ & $30 \%$ \\
\end{tabular}

${ }^{1}$ Only 81 of these correspond to regulated utilities

${ }^{2}$ These are conglomerate firms. 
Table 3

CEO appointment decisions and ex-ante managerial ownership.

This table is based on 1,123 CEO replacements occurred during 1993-2002, and reports the ownership of top-managers as of the year before the CEO appointment. Departing CEOs are excluded from the sample. Ownership, alpha, is defined as the number of previously acquired/granted common or restricted stock held by managers plus the number of unexercised stock options held by management as a percentage of total shares outstanding (unexercised stock options include in and out-of the-money options).

\begin{tabular}{lcc|cc}
\hline & \multicolumn{2}{c|}{$\begin{array}{c}\text { Firms With Inside Replacements } \\
\text { Appointed }\end{array}$} & Not Appointed & \multicolumn{2}{c}{ Appointed } & Not Appointed \\
\cline { 2 - 5 } & 1.354 & 0.538 & 0.000 & 0.597 \\
Mean & 0.545 & 0.228 & 0.000 & 0.261 \\
Median & 781 & 2,295 & 342 & 1,360 \\
\# Obs. & & & & \\
\hline
\end{tabular}


Table 4

Probit models of insider appointment

Each observation corresponds to an executive in one of the 781 firm-years with inside replacements. Outside replacements are excluded from the sample. The table reports the marginal effects of Probit models of the probability that a particular insider is appointed CEO. Marginal effects are evaluated at the mean of continuous variables. For dummy variables, the marginal effects represent the increase in the probability when the variable increases from zero to one. All independent variables are lagged one year. Alpha is the number of previously acquired/granted common or restricted stock held by managers plus the number of unexercised stock options held by management as a percentage of total shares outstanding. Devalpha is the difference between $\ln (1+$ alpha) for an executive and its median value across all the executives in the firm (other than the departing CEO). Maxowner equals one if the executive has the highest ownership among all executives (other than the departing CEO). Salary and bonus are measured in $\$$ thousands. Tenure is the number of years an executive has been in the company. Robust z-statistics are in parentheses below each estimate. ${ }^{*}, * *, * *$ means significant at $10 \%, 5 \%$, and $1 \%$, respectively.

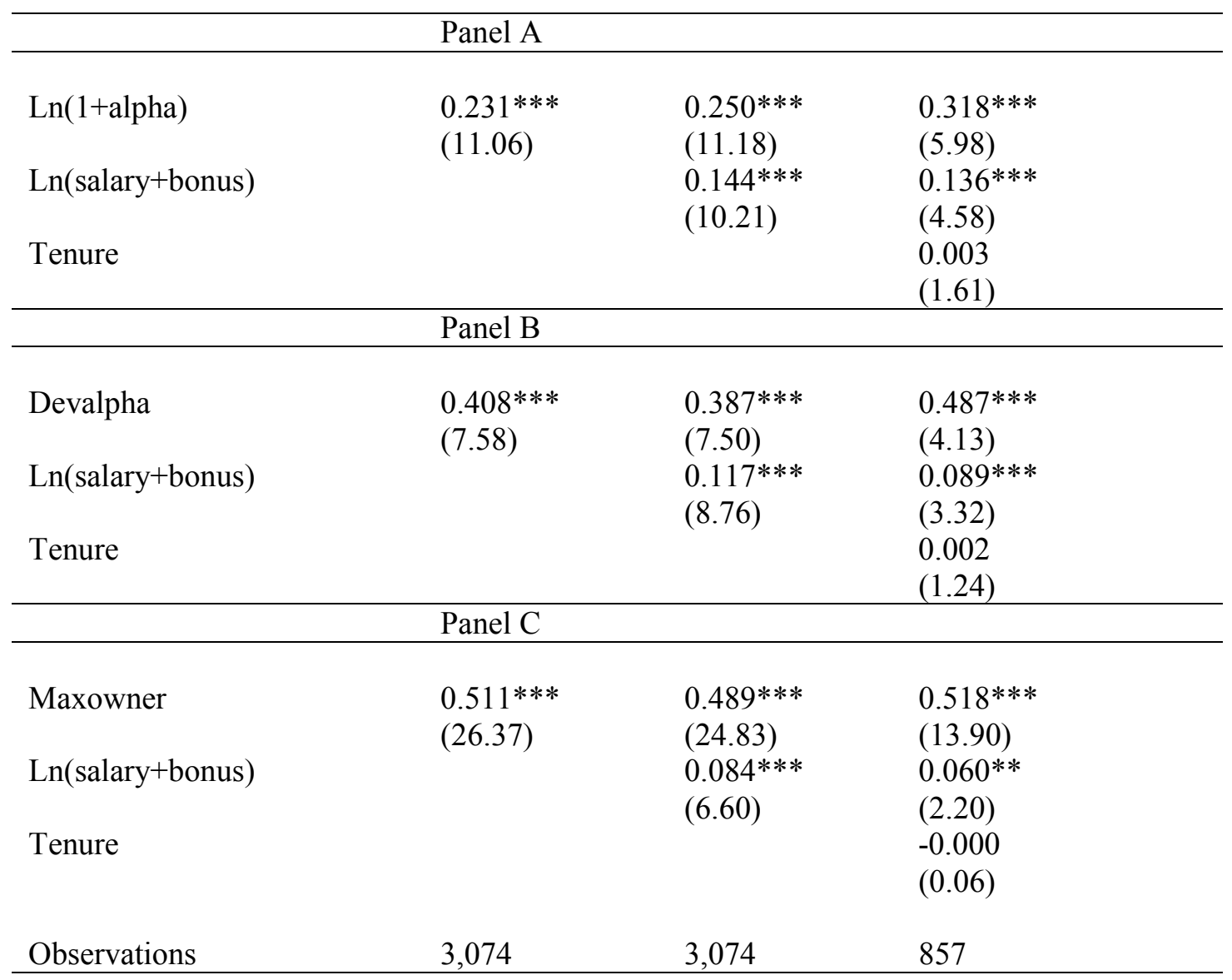




\section{Table 5}

\section{CEO appointment decisions and ex-ante managerial ownership, by quintiles}

Each observation corresponds to an executive in one of the 781 firm-years with inside replacements. Outside replacements are excluded from the sample. The table reports the marginal effects of Probit models of the probability that a particular insider is appointed $\mathrm{CEO}$, as a function of ownership quintiles. Marginal effects are evaluated at the mean of continuous variables. For dummy variables, the marginal effects represent the increase in the probability when the variable increases from zero to one. Departing CEOs are excluded from the sample in all cases. All independent variables are lagged one year. Quintile 1 is the omitted category in all regressions. Alpha is the number of previously acquired/granted common or restricted stock held by managers plus the number of unexercised stock options held by management as a percentage of total shares outstanding. Salary and bonus are measured in $\$$ thousands. Tenure is the number of years an executive has been in the company. Robust z-statistics are in parentheses below each estimate. *,**,*** means significant at $10 \%, 5 \%$, and $1 \%$, respectively.

\begin{tabular}{lllll}
\hline Q2(alpha) & 0.021 & 0.024 & 0.024 & $0.134^{*}$ \\
& $(0.77)$ & $(0.86)$ & $(0.86)$ & $(1.88)$ \\
Q3(alpha) & $0.054^{* *}$ & $0.058^{* *}$ & $0.058^{* *}$ & 0.049 \\
& $(1.96)$ & $(2.10)$ & $(2.10)$ & $(0.70)$ \\
Q4(alpha) & $0.150^{* * *}$ & $0.181^{* * *}$ & $0.181^{* * *}$ & $0.190^{* * *}$ \\
& $(5.42)$ & $(6.31)$ & $(6.31)$ & $(2.90)$ \\
Q5(alpha) & $0.365^{* * *}$ & $0.413^{* * *}$ & $0.413^{* * *}$ & $0.455^{* * *}$ \\
& $(12.82)$ & $(13.80)$ & $(13.80)$ & $(7.32)$ \\
Ln(salary+bonus) & & $0.153^{* * *}$ & $0.153^{* * *}$ & $0.168^{* * *}$ \\
Tenure & & $(10.95)$ & $(10.95)$ & $(5.03)$ \\
& & & & 0.003 \\
Observations & & & & $(1.39)$ \\
\hline
\end{tabular}


Table 6

Probit models of outside CEO replacements

The table reports marginal effects of Probit models of the probability that the firm chooses an outside CEO replacement. Marginal effects are evaluated at the mean of continuous variables. For dummy variables, the marginal effects represent the increase in the probability when the variable increases from zero to one. Max(alpha), Max(tenure), and Max(lnsalbon) are the maximum alpha, maximum tenure, and maximum $\ln$ (salary+bonus) across all executives the year preceding the CEO appointment, but excluding the Departing CEO. Ln(assets) is the natural logarithm of the firm's assets. Return-ind-adj and ROA-ind-adj. are industry-adjusted return to shareholders and ROA, with industries defined at the 2-digit SIC codes. All independent variables are lagged one year. The original sample is the 1,123 replacements. Robust zstatistics are in parentheses below each estimate. ${ }^{*}, * *, * *$ means significant at $10 \%, 5 \%$, and $1 \%$, respectively.

\begin{tabular}{|c|c|c|c|c|c|c|}
\hline & $(1)$ & $(2)$ & (3) & (4) & $(5)$ & (6) \\
\hline $\operatorname{Max}($ alpha) & $\begin{array}{l}-0.008 * * \\
(2.00)\end{array}$ & $\begin{array}{l}-0.008 * * \\
(2.08)\end{array}$ & $\begin{array}{l}-0.011 * * \\
(2.54)\end{array}$ & $\begin{array}{l}-0.020 * * * \\
(3.10)\end{array}$ & $\begin{array}{l}-0.018 * * * \\
(3.17)\end{array}$ & $\begin{array}{l}-0.019 * * \\
(2.19)\end{array}$ \\
\hline ROA-ind-adj. & & $\begin{array}{l}-0.004 * * * \\
(3.70)\end{array}$ & $\begin{array}{l}-0.003 * * * \\
(3.11)\end{array}$ & $\begin{array}{l}-0.002^{*} \\
(1.96)\end{array}$ & $\begin{array}{l}-0.002 * \\
(1.73)\end{array}$ & $\begin{array}{l}-0.002^{*} \\
(1.79)\end{array}$ \\
\hline Return-ind-adj. & & & $\begin{array}{l}-0.001^{*} \\
(1.89)\end{array}$ & $\begin{array}{l}-0.001 * * \\
(2.09)\end{array}$ & $\begin{array}{l}-0.001^{* *} \\
(1.97)\end{array}$ & $\begin{array}{l}-0.001 \\
(1.34)\end{array}$ \\
\hline Ln(assets) & & & & $\begin{array}{l}-0.045^{* * * *} \\
(5.21)\end{array}$ & $\begin{array}{l}0.007 \\
(0.60)\end{array}$ & $\begin{array}{l}0.017 \\
(1.09)\end{array}$ \\
\hline $\operatorname{Max}($ lnsalbon) & & & & & $\begin{array}{l}-0.201^{* * * *} \\
(5.79)\end{array}$ & $\begin{array}{l}-0.206^{* * *} \\
(4.60)\end{array}$ \\
\hline Max(tenure) & & & & & & $\begin{array}{l}-0.003 * \\
(1.70)\end{array}$ \\
\hline Observations & 1,123 & 1,123 & 1,103 & 1,103 & 1,101 & 652 \\
\hline
\end{tabular}


Table 7

\section{Changes in ownership surrounding the CEO replacement}

The change in ownership includes the change in alpha from one date to another, and includes both stock and stock options. The executives in are classified as "Departing CEOs", "New Insider CEOs", and "NonAppointed Top Managers" (these executives are not CEOs at t-1 and are not appointed CEOs at time t). The last group is decomposed into "Strong Candidates", which have the highest ownership among the nonappointed insiders in each firm, and Other Executives. In Panel A, the entries at date $t$ report the changes in alpha conditional on being in the company at date t- 1 and staying in the company at date t. Similarly, the entries labeled date $t+1$ show the changes in alpha conditional on being in the company at date $t$, and staying in the company at date $t+1$. Thus, in Panel A there are missing observations due to executives leaving the company at dates $t$ or $t+1$. Column 2 only includes inside CEO appointments, and excludes outside CEO replacements at date $t$. In Panel $B$, we address the attrition problem by setting alpha at dates $t$ and $t+1$ equal to zero if the executive leaves the company at dates $t$ and $t+1$, respectively. Thus panel $B$ contains no missing observations.

\begin{tabular}{|c|c|c|c|c|c|}
\hline & $\begin{array}{c}\text { Departing } \\
\text { CEOs } \\
(1)\end{array}$ & $\begin{array}{c}\text { New Insider } \\
\text { CEOs } \\
(2)\end{array}$ & $\begin{array}{c}\text { Non-Appointed } \\
\text { Top Managers } \\
\text { (3) }\end{array}$ & $\begin{array}{c}\text { Strong } \\
\text { Candidates } \\
(4) \\
\end{array}$ & $\begin{array}{c}\text { Other } \\
\text { Executives } \\
(5) \\
\end{array}$ \\
\hline & \multicolumn{5}{|c|}{ Panel A: Original data } \\
\hline \multicolumn{6}{|l|}{ Date t: } \\
\hline Mean & -0.355 & 0.32 & 0.029 & -0.001 & 0.043 \\
\hline Median & -0.053 & 0.104 & 0.018 & 0.013 & 0.019 \\
\hline \# executives & 969 & 781 & 2,579 & 841 & 1,738 \\
\hline \multicolumn{6}{|l|}{ Date $\mathrm{t}+1$ : } \\
\hline Mean & -0.55 & 0.079 & 0.004 & -0.061 & 0.037 \\
\hline Median & -0.03 & 0.07 & 0.019 & 0.014 & 0.021 \\
\hline \# executives & 208 & 654 & 1,540 & 513 & 1,027 \\
\hline \multicolumn{6}{|c|}{ Panel B: Ownership equals zero if the executive leaves the firm } \\
\hline \multicolumn{6}{|l|}{ Date t: } \\
\hline Mean & -0.546 & 0.32 & -0.146 & -0.325 & -0.067 \\
\hline Median & -0.099 & 0.104 & -0.001 & -0.006 & 0 \\
\hline \# executives & 1,123 & 781 & 3,651 & 1,129 & 2,522 \\
\hline \multicolumn{6}{|l|}{ Date $\mathrm{t}+1$ : } \\
\hline Mean & -2.026 & -0.192 & -0.214 & -0.389 & -0.13 \\
\hline Median & -0.658 & 0.041 & -0.023 & -0.047 & -0.013 \\
\hline \# executives & 969 & 781 & 2,579 & 841 & 1,738 \\
\hline
\end{tabular}


Table 8

Probit models of reductions in ownership

The table reports the marginal effects of Probit models of the probability that any given executive will reduce his/her alpha (comprising both stock and stock options) in the year of the CEO replacement. Marginal effects are evaluated at the mean of continuous variables. For dummy variables, the marginal effects represent the increase in the probability when the variable increases from zero to one. We use dummy variables to classify executives into four groups: Departing CEOs, New Insider CEOs, Strong Candidates and Other Executives. These last two groups combined contain all non-appointed managers. The Strong Candidates have the highest alpha among all non-appointed managers, while Other Executives include the rest of the non-appointed executives. Executives who are outside CEO replacements are excluded from the sample. Shareholder return is the total annual return to shareholders, including the reinvestment of dividends. Salary and bonus are measured in $\$$ thousands. Tenure is the number of years an executive has been in the company. In all regressions, New Insider CEOs are the omitted category. All continuous independent variables are lagged one year. Robust zstatistics are in parentheses below each estimate. *,**,*** means significant at $10 \%, 5 \%$, and $1 \%$, respectively.

\begin{tabular}{|c|c|c|c|c|}
\hline & $(1)$ & (2) & (3) & $(4)$ \\
\hline Departing CEOs & $\begin{array}{l}0.460 * * * \\
(18.47)\end{array}$ & $\begin{array}{l}0.463 * * * \\
(18.39)\end{array}$ & $\begin{array}{l}0.468 * * * \\
(18.30)\end{array}$ & $\begin{array}{l}0.496 * * * \\
(12.69)\end{array}$ \\
\hline Strong Candidates & $\begin{array}{l}0.229^{* * * *} \\
(8.69)\end{array}$ & $\begin{array}{l}0.232 * * * \\
(8.77)\end{array}$ & $\begin{array}{l}0.221 * * * \\
(8.28)\end{array}$ & $\begin{array}{l}0.305 * * * \\
(6.45)\end{array}$ \\
\hline Other Executives & $\begin{array}{l}0.119 * * * \\
(5.19)\end{array}$ & $\begin{array}{l}0.126^{* * * *} \\
(5.49)\end{array}$ & $\begin{array}{l}0.114 * * * \\
(4.82)\end{array}$ & $\begin{array}{l}0.115^{* * * *} \\
(2.80)\end{array}$ \\
\hline Shareholder Return $_{\mathrm{t}-1}$ & & $\begin{array}{l}0.001 * * * \\
(5.28)\end{array}$ & $\begin{array}{l}0.001 * * * \\
(5.39)\end{array}$ & $\begin{array}{l}0.001 * * * \\
(4.47)\end{array}$ \\
\hline $\operatorname{Ln}($ salary+bonus) $\mathrm{t}-1$ & & & $\begin{array}{l}-0.025^{* *} \\
(2.12)\end{array}$ & $\begin{array}{l}-0.050^{* * *} \\
(2.58)\end{array}$ \\
\hline Tenure $_{t-1}$ & & & & $\begin{array}{l}-0.000 \\
(0.03)\end{array}$ \\
\hline Observations & 4,329 & 4,267 & 4,251 & 1,475 \\
\hline
\end{tabular}


Table 9

Probit models of reductions in ownership for non-appointed managers

The table reports the marginal effects of Probit models of the probability that any given executive will reduce his/her alpha in the year of the CEO replacement. Marginal effects are evaluated at the mean of continuous variables. For dummy variables, the marginal effects represent the increase in the probability when the variable increases from zero to one. Departing CEOs and new CEOs are excluded from the sample. Alpha is the number of previously acquired/granted common or restricted stock held by managers plus the number of unexercised stock options held by management as a percentage of total shares outstanding. Devalpha is the difference between $\ln (1+$ alpha) for an executive and its median value across all the executives in the firm (other than the departing CEO). Strong Candidate equals one if the executive has the highest ownership among all non-appointed executives. Salary and bonus are measured in $\$$ thousands. Tenure is the number of years an executive has been in the company. All independent variables are lagged one year. Robust z-statistics are in parentheses below each estimate. $*, * *, * * *$ means significant at $10 \%, 5 \%$, and $1 \%$, respectively.

\begin{tabular}{|c|c|c|c|c|c|}
\hline & Panel A & & & & \\
\hline Ln(1+alpha) & $\begin{array}{l}0.297 * * * \\
(9.85)\end{array}$ & $\begin{array}{l}0.293 * * * \\
(9.84)\end{array}$ & $\begin{array}{l}0.291 * * * \\
(9.82)\end{array}$ & $\begin{array}{l}0.286 * * * \\
(9.61)\end{array}$ & $\begin{array}{l}0.325 * * * \\
(5.01)\end{array}$ \\
\hline InsideCEO & & $\begin{array}{l}-0.066^{* * *} \\
(3.34)\end{array}$ & $\begin{array}{l}-0.084^{* * * *} \\
(4.16)\end{array}$ & $\begin{array}{l}-0.081 * * * \\
(3.98)\end{array}$ & $\begin{array}{l}-0.182 * * * \\
(4.29)\end{array}$ \\
\hline Return & & & $\begin{array}{l}0.001 * * * \\
(5.48)\end{array}$ & $\begin{array}{l}0.001 * * * \\
(5.46)\end{array}$ & $\begin{array}{l}0.001 * * * \\
(3.64)\end{array}$ \\
\hline Ln(salary+bonus) & & & & $\begin{array}{l}-0.002 \\
(0.15)\end{array}$ & $\begin{array}{l}-0.010 \\
(0.33)\end{array}$ \\
\hline Tenure & & & & & $\begin{array}{l}0.005^{* *} \\
(2.39)\end{array}$ \\
\hline
\end{tabular}

\begin{tabular}{|c|c|c|c|c|c|}
\hline & Panel B & & & & \\
\hline Strong Candidate & $\begin{array}{l}0.099 * * * \\
(5.06)\end{array}$ & $\begin{array}{l}0.108 * * * \\
(5.45)\end{array}$ & $\begin{array}{l}0.104 * * * \\
(5.21)\end{array}$ & $\begin{array}{l}0.105^{* * *} \\
(5.25)\end{array}$ & $\begin{array}{l}0.183 * * * \\
(4.16)\end{array}$ \\
\hline InsideCEO & & $\begin{array}{l}-0.085^{* * * *} \\
(4.31)\end{array}$ & $\begin{array}{l}-0.101^{* * *} \\
(5.01)\end{array}$ & $\begin{array}{l}-0.092 * * * \\
(4.52)\end{array}$ & $\begin{array}{l}-0.182 * * * \\
(4.41)\end{array}$ \\
\hline Return & & & $\begin{array}{l}0.001 * * * \\
(5.46)\end{array}$ & $\begin{array}{l}0.001 * * * \\
(5.51)\end{array}$ & $\begin{array}{l}0.001 * * * \\
(3.79)\end{array}$ \\
\hline Ln(salary+bonus) & & & & $\begin{array}{l}-0.024 \\
(1.59)\end{array}$ & $\begin{array}{l}-0.058 * * \\
(1.97)\end{array}$ \\
\hline \multirow[t]{2}{*}{ Tenure } & & & & & $\begin{array}{l}0.005^{* *} \\
(2.13)\end{array}$ \\
\hline & Panel C & & & & \\
\hline Devalpha & $\begin{array}{l}0.255^{* * * *} \\
(6.01)\end{array}$ & $\begin{array}{l}0.246^{* * * *} \\
(5.89)\end{array}$ & $\begin{array}{l}0.250 * * * \\
(5.98)\end{array}$ & $\begin{array}{l}0.258 * * * \\
(6.00)\end{array}$ & $\begin{array}{l}0.275^{* * *} \\
(3.49)\end{array}$ \\
\hline InsideCEO & & $\begin{array}{l}-0.065^{* * * *} \\
(3.30)\end{array}$ & $\begin{array}{l}-0.081^{* * * *} \\
(4.05)\end{array}$ & $\begin{array}{l}-0.071^{* * * *} \\
(3.49)\end{array}$ & $\begin{array}{l}-0.157^{* * *} \\
(3.81)\end{array}$ \\
\hline Return & & & $\begin{array}{l}0.001 * * * \\
(5.63)\end{array}$ & $\begin{array}{l}0.001 * * * \\
(5.68)\end{array}$ & $\begin{array}{l}0.001 * * * \\
(3.93)\end{array}$ \\
\hline Ln(salary+bonus) & & & & $\begin{array}{l}-0.032 * \\
(2.12)\end{array}$ & $\begin{array}{l}-0.062^{*} \\
(2.07)\end{array}$ \\
\hline Tenure & & & & & $\begin{array}{l}0.005^{* * *} \\
(2.54)\end{array}$ \\
\hline Observations & 2,579 & 2,579 & 2,540 & 2,533 & 620 \\
\hline
\end{tabular}




\section{Table 10}

\section{Probit models of non-appointed executive departure}

The table reports the marginal effects of Probit models of the probability that a non-appointed executive leaves the firm the year of a new CEO appointment. Marginal effects are evaluated at the mean of continuous variables. For dummy variables, the marginal effects represent the increase in the probability when the variable increases from zero to one. The sample is restricted to executives that are not the departing CEO, and were not appointed CEOs. All independent variables are lagged one year. Devalpha is the difference between $\ln (1+$ alpha $)$ for an executive and its median value across all the executives in the firm (other than the departing CEO). Alpha is the number of previously acquired/granted common or restricted stock held by managers plus the number of unexercised stock options held by management as a percentage of total shares outstanding. InsideCEO equals one if the firm's new CEO is an insider, and zero otherwise. Return-ind-adj and ROA-indadj. are industry-adjusted return to shareholders and ROA, with industries defined at the 2-digit SIC codes. Tenure is the number of years an executive has been in the company. Robust z-statistics are in parentheses below each estimate. *, **, $* * *$ means significant at $10 \%, 5 \%$, and $1 \%$, respectively.

\begin{tabular}{|c|c|c|c|c|c|c|c|}
\hline & (1) & (2) & (3) & (4) & (5) & (6) & (7) \\
\hline Devalpha & $\begin{array}{l}0.053 * * \\
(1.98)\end{array}$ & & $\begin{array}{l}0.115 * * * \\
(3.00)\end{array}$ & $\begin{array}{l}0.091^{* *} \\
(2.39)\end{array}$ & $\begin{array}{l}0.138^{* * * *} \\
(2.71)\end{array}$ & $\begin{array}{l}0.163 * * * \\
(2.98)\end{array}$ & $\begin{array}{l}0.365 * * * \\
(3.71)\end{array}$ \\
\hline $\operatorname{Ln}(1+$ alpha $)$ & & $\begin{array}{l}-0.005 \\
(0.25)\end{array}$ & $\begin{array}{l}-0.066^{* *} \\
(2.31)\end{array}$ & $\begin{array}{l}-0.061^{* *} \\
(2.12)\end{array}$ & $\begin{array}{l}-0.064^{* *} \\
(2.20)\end{array}$ & $\begin{array}{l}-0.086^{* * * *} \\
(2.75)\end{array}$ & $\begin{array}{l}-0.183 * * * \\
(2.66)\end{array}$ \\
\hline InsideCEO & & & & $\begin{array}{l}-0.129 * * * \\
(8.19)\end{array}$ & $\begin{array}{l}-0.127 * * * \\
(8.04)\end{array}$ & $\begin{array}{l}-0.115^{* * * *} \\
(6.98)\end{array}$ & $\begin{array}{l}-0.102 * * * \\
(3.07)\end{array}$ \\
\hline Devalpha*InsideCEO & & & & & $\begin{array}{l}-0.083 \\
(1.51)\end{array}$ & $\begin{array}{l}-0.100^{*} \\
(1.73)\end{array}$ & $\begin{array}{l}-0.317 * * * \\
(2.80)\end{array}$ \\
\hline Return-ind-adj. & & & & & & $\begin{array}{l}-0.000 * * \\
(2.52)\end{array}$ & $\begin{array}{l}-0.000 \\
(1.19)\end{array}$ \\
\hline ROA-ind-adj. & & & & & & $\begin{array}{l}-0.002 * * * \\
(3.74)\end{array}$ & $\begin{array}{l}-0.001 * \\
(1.96)\end{array}$ \\
\hline Ln(salary+bonus) & & & & & & $\begin{array}{l}0.022 * \\
(1.70)\end{array}$ & $\begin{array}{l}0.032 \\
(1.22)\end{array}$ \\
\hline Tenure & & & & & & & $\begin{array}{l}-0.001 \\
(0.57)\end{array}$ \\
\hline Observations & 3,651 & 3,651 & 3,651 & 3,651 & 3,651 & 3,579 & 888 \\
\hline
\end{tabular}


Figure 2

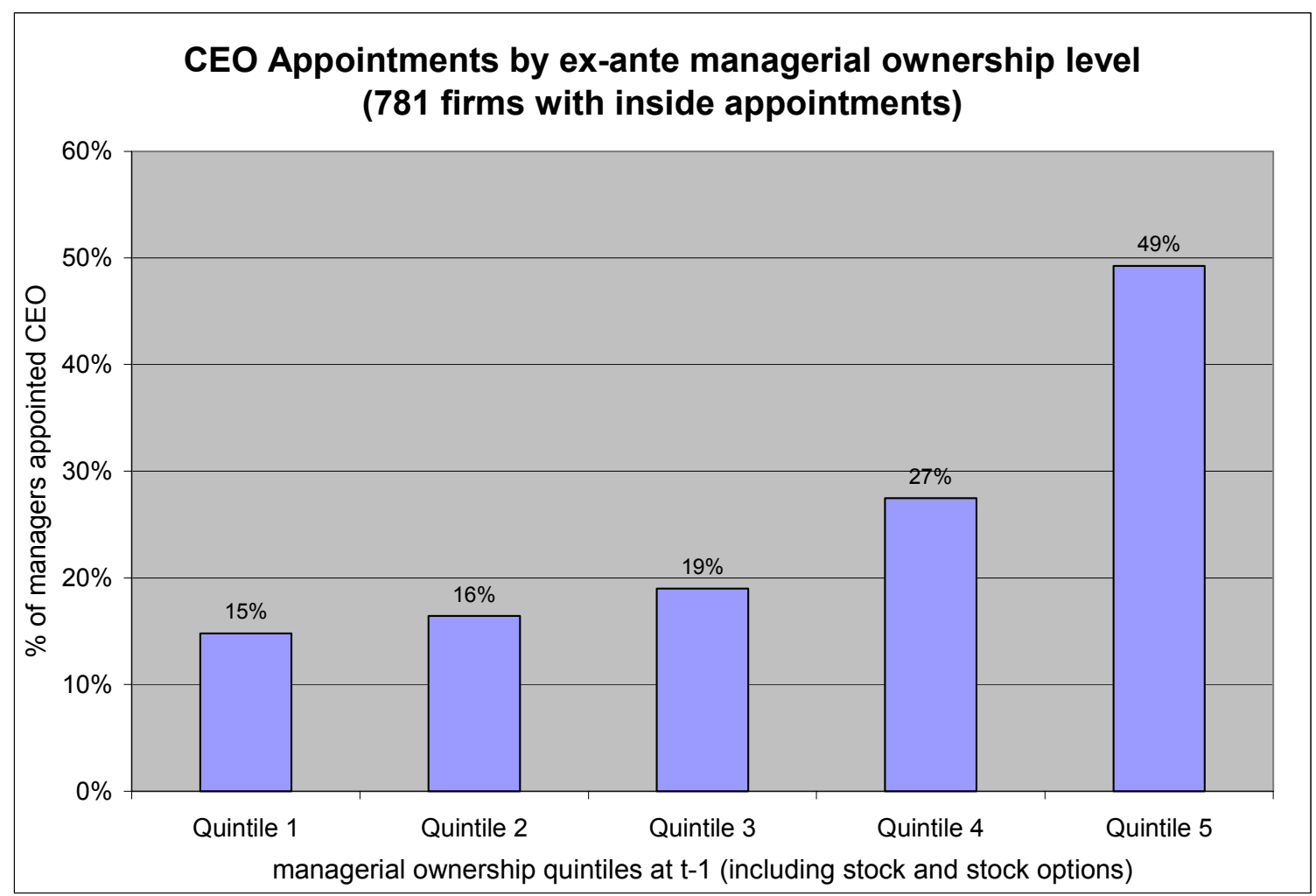

